Dokumenttype NOU 1993:17 Dokumentdato 1993-05-05

$\begin{array}{ll}\text { Tittel } & \text { Levekår i Norge.Er graset grønt for alle? } \\ \text { Utvalgsnavn } & \text { Levekårsutvalget } \\ \text { Utvalgsleder } & \text { Longva, Svein } \\ \text { Utgiver } & \text { Finans-og tolldepartementet } \\ \text { Oppnevnt } & 1992-12-04 \quad \text { Sider } \\ \text { Kapittel } & 1 \quad \text { Levekår i Norge. Er graset grønt for alle } \\ & 1.1 \text { Innledning } \\ & 1.2 \text { Utvalgets mandat og arbeid }\end{array}$

\title{
LEVEKÅR I NORGE
}

Er graset grønt for alle?

Kapittel 1

SAMMENFATNING

\subsection{INNLEDNING}

De fleste fikk bedre levekåri løpet av 1980-tallet. Nærliggende eksempler er pensjonistenes klart bedrede inntektsforhold og den vesentlige hevingen i boligstandarden, som også har omfattet mange av de dårligst stilte. Inntektsfordelingenmellom ulike inntektsgrupper ser ut til å ha endret seg lite.

Økonomiske og sosiale virkninger av problemene på arbeidsmarkedet var de viktigste negative trekk ved utviklingen i levekårene.

Dette er utvalgets hovedkonklusjoner etter en bred gjennomgang av ulike sider ved befolkningens levekår og etter å ha studert utviklingen for enkeltgrupper.

Noen viktige reservasjoner må framheves. For det første fanger datamaterialet utvalget har brukt i analysen av inntektsfordelingen, bare i begrenset grad opp kapital- og næringsinntekter med helt eller delvis skattefritak, blant disse også gevinster og tap ved kjøp og salg av formuesobjekter. Utviklingen i slike uregistrerte inntekter var mye omtalt på 1980tallet. Disse svakhetene i datamaterialet kan ha påvirket våre konklusjoner om utviklingen gjennom 1980-tallet. For det andre er tyngden av vårt datamateriale basert på utvalgsundersøkelser. Dette betyr at vi står i fare for å overse eller utelate grupper eller utviklingstrekk som faller utenfor hovedbildet, både i den positive og negative retning. Eksempler på dette kan være utviklingen for de aller rikeste og for de bostedsløse. Endelig har vi bare i begrenset grad vært i stand til å følge enkeltpersoner over tid og har derfor hovedsakelig vurdert levekårene for grupper.

På tross av de store omskiftingene i norsk økonomi på 1980-tallet ser det ut til at vi gikk ut av tiåret med omtrent samme inntektsfordeling som vi gikk inn med. Stabiliteten i inntektsfordelingen finner vi igjen både mellom ulike inntektsgrupper og mellom ulike generasjoner. Hovedkonklusjonene blir de samme selv om vi varierer gruppene som sammenlignes og måler inntekten på forskjellig måte. Stabiliteten for 1980-tallet sett under ett dekker imidlertid over at vårt tallmateriale viser en svak tendens til utjevning fram til 1986 og noe økte forskjeller mot slutten av tiåret. Når levekårsutviklingen skal beskrives er utviklingen $\mathrm{i}$ arbeidsmarkedet og trygdesystemet av grunnleggende betydning. Inntektsgivende arbeid og offentlige overføringer er de viktigste fordelingsmekanismer for inntekt og levekår. 
Trygdesystemet er blitt en stadig viktigere inntektskilde.

Arbeidsmarkedet er derimot, etter en sterk vekstperiode, blitt vesentlig mindre tilgjengelig i de siste 4-5 år. Funksjonsfriske i alderen 25 til 55 år dominerer arbeidsmarkedet. Yngre aldersgrupper er henvist til utdanningssystemet, og de eldre må i større grad basere sitt livsopphold på trygd.

Arbeidsledigheten har skiftet karakter. Det er klart flere langtidsledige nå enn i begynnelsen av 1980-årene, særlig blant unge og eldre. De langtidsledige har langt større vansker enn yrkesaktive med å møte økonomiske forpliktelser. Selv om få arbeidsledige sier de er utsatt for psykiske plager, virker de likevel klart mer utsatt enn yrkesbefolkningen forøvrig.

Skole- og undervisningssystemethar fått større betydning. Nesten alle grunnskoleelever går nå direkte over $\mathrm{i}$ videregående utdanning. Den sterke veksten $i$ utdanningssystemet har gitt mange flere enn før muligheter til videre utdanning, og Norge har fătt en klart bedre utdannet arbeidskraft. Valg av utdanning er fortsatt sterkt avhengig av kjønn og det er kødannelser på enkelte områder i utdanningssystemet. Selv om utdanningssystemet fortsatt i hovedsak er en kvalifiseringsarena har det de siste årene i noen grad fått preg av oppbevaring.

Sammenhengen mellom utdanning og arbeid har endret seg. Utdanning kvalifiserer fremdeles til arbeidsmarkedet, men en trenger mer utdanning nå enn tidligere for å få en bestemt jobb. Arbeidssøkere uten utdanning utover grunnskolen har få muligheter og gruppen ungdom med lav utdanning har i de senere år fått en klart vanskeligere start på det voksne liv. Offentlige tjenester innenfor undervisning, helse og omsorg har blitt stadig viktigere for folks levekår og det har vært en betydelig vekst på disse områdene gjennom 1980-tallet. Likevel påpeker utvalget enkelte problemområder, for eksempel i deler av eldreomsorgen og på den betydelige forskjellen mellom kommuner når det gjelder omfanget av kommunal tjenesteyting. De regionale forskjeller i levekår synes likevel generelt å ha blitt redusert. Men ulikhetene innenfor storbyområder, som for eksempel Oslo, er større enn mellom ulike deler av landet. Gjennom 1980-tallet har en del grupper i økende grad fått behov for økonomisk bistand. Sosialhjelp har stor betydning som inntektssikring blant unge, innvandrere og enslige menn, særlig i storbyene. Enslige forsørgere, særlig mødre med overgangsstønad, er også ofte avhengig av slik hjelp fra det offentlige. Kombinasjonen arbeidsinntekt og sosialhjelp har blitt mindre vanlig, og kombinasjonen trygd og sosialhjelp mer vanlig. I utviklingen av helsetilstand og sosiale forhold har det vært enkelte klare positive utviklingstrekk. Levealderen har fortsatt å øke og det er tendenser til bedre fysisk helse blant eldre menn. Videre har familie- og vennskapskontakten blitt sterkere. Enkelte sider ved helsetilstanden har utviklet seg i negativ retning, blant annet forekomsten av muskel-/skjelettlidelser blant kvinner. Den mest entydige negative sosiale utviklingen er $ø$ kningen i kriminaliteten, spesielt de grove voldsforbrytelsene. Omskifteligheten i familierelasjonene har blitt større, og en av konsekvensene er at flere barn rammes av samlivsoppløsninger. Et viktig spørsmål er om personer med dårlige levekår etterhvert får det bedre, eller om de vil slite med lav levestandard og dårlige sosiale forhold over lang tid. Det er også viktig å avdekke om slike grupper vokser. For noen er problemene stort sett midlertidige, for eksempel for ungdom generelt og for enslige forsørgere. Det er imidlertid fare for at langtidsledige og en del ungdom med lav utdanning, kan ende opp i en permanent situasjon med relativt dårlige levekår hvis de ikke kommer inn $\mathrm{i}$ arbeidsmarkedet. Det er også viktig å peke på at vi på 1980-tallet ble mer utsatt for brå skiftinger i levekår for den enkelte. På noen områder og for noen grupper er riktignok sårbarheten redusert, 
f.eks. ved at flere husholdninger nå har mer enn $\mathrm{n}$ inntektstaker. På andre områder har imidlertid sårbarheten økt, for eksempel ved at sikkerheten for arbeid for den enkelte er klart redusert og ved økte svingninger i boligprisene. En videre drøfting av utviklingsperspektivet på slike områder ligger imidlertid utenfor mandatet til denne utred- ningen.

\subsection{UTVALGETS MANDAT OG ARBEID}

Utvalget ble gitt et meget omfattende og bredt mandat. I tillegg til en drøfting av sentrale metode- og begrepsmessige spørsmål var det viktigste en empirisk analyse av utviklingen i viktige levevilkårskomponenter i Norge fra 1980 og fram til idag. En analyse av utviklingen i inntektsfordelingen sto også sentralt. Innenfor den tidsrammen som sto til disposisjon, var utvalget i det alt vesentlige henvist til å utnytte eksisterende statistikk og forskningsarbeid. På viktige områder forelå det forholdsvis fersk statistikk og dessuten analyser som dels var publisert og dels fortsatt var under bearbeiding. Dette materiale ble velvillig stilt til rådighet for utvalget. På noen få avgrensede områder tok utvalget initiativ til ny analyse.

Utvalget har ikke maktet å gjennomføre en systematisk gjennomgang av viktige mangler ved tilgjengelig informasjon om levekårsforhold i Norge, slik mandatet ber om. Utvalget mener imidlertid at en slik gjennomgang er svært viktig og vil komme tilbake med et forslag om en hensiktsmessig framgangsmåte.

Kapittel 1 Levekår i Norge. Er graset grønt for alle 1.3 Hva er levekår og hvordan kan de måles

\subsection{HVA ER LEVEKÅR OG HVORDAN KAN DE MÅLES}

Utvalget har diskutert ulike tilnærminger til analyser av levekår, og har valgt å basere sin framstilling på den såkalte nordiske tilnærmingsmåten. Denne er karakterisert ved:

* Levekår påvirkes av individuelle ressurser som individene disponerer i form av eksempelvis inntekt, formue, helse og kunnskaper, og som de kan bruke til å styre egne liv. I tillegg vil tilgangen til kollektive ressurser, f.eks. organisasjoner, være av vesentlig betydning.

* Levekårene påvirkes av egenskaper ved de områder eller arenaer ressursene setter inn på, f.eks. grad av trengsel i utdanningssystemet, arbeidsmarkedet og boligmarkedet. * Levekår omfatter et bredt sett av komponenter, særlig helse, sysselsetting, arbeidsvilkår, økonomiske ressurser, kunnskaper, utdanningsmuligheter, familie og sosiale relasjoner, bosted og nærmiljø, rekreasjon og kultur, sikkerhet til liv og eiendom, og politiske ressurser og rettigheter.

* Levekår måles ved å skape et helhetsbilde basert på omfattende statistisk kartlegging av objektive mål på levekår.

Det er beskrivelsen av slike arenaer og levekårskomponenter utvalget har lagt vekt på. I tillegg til utviklingen over tid, har utvalget også vært opptatt av endringen i fordeling av levekår i og mellom ulike grupper i befolkningen. 
Kapittel 1 Levekår i Norge. Er graset grønt for alle

1.4 Utviklingen i befolkning, miljøforhold og økonomi

1.4.1 Befolkning

1.4.2 Miljøforhold

\subsection{UTVIKLINGEN I BEFOLKNING, MILJØFORHOLD OG ØKONOMI}

Utviklingen i befolkning, miljøforhold og økonomi er viktige rammevilkår for levekårsutviklingen. Utvalget har lagt vekt på å sette analysen inn i et bredt perspektiv ved å ta utgangspunkt i den nasjonale utviklingen på disse områdene. 1.4.1. Befolkning

Færre unge, flere eldre

Befolkningens størrelse og sammensetning har betydning både for arbeidsstyrkens størrelse, og dermed for mulighetene til å framskaffe varer og tjenester, og for hva slags velferdsgoder som etterspørres. Befolkningen har vokst relativt jevnt med om lag 0,5 prosent pr. år fra 1970 til 1992. I denne perioden har det skjedd en vrid- ning av befolkningsstrukturen ved at an- delen personer i alderen 0-19 år har blitt redusert, mens andelen personer 67 år og over har økt. Disse aldersgrupper betraktes ofte som mer kostnadskrevende for velferds- statens økonomi enn andre. Samlet sett har disse gruppenes andel av befolkningen avtatt noe.

Antall personer pr. husholdning har avtatt i perioden, og det har blitt flere enslige, og flere enslige foreldre med barn. Det har bare vært mindre endringer i den regionale befolkningsfordelingen på 1980-tallet.

\subsubsection{Miljøforhold}

Reduksjon av flere miljøskadelige utslipp....

Etter utvalgets oppfatning er det hovedsakelig utviklingen i lokale miljøfaktorer som har umiddelbar betydning for velferd og trivsel. På en del områder har det vært en positiv utvikling i lokale miljøforhold i de senere år. Utslippene av SO2 i Norge har blitt sterkt redusert etter 1980. Utslipp av bly har også gått sterkt ned. Industrien har redusert sine utslipp av en rekke miljøgifter etter 1985, og ved flere prøvetakingsstasjoner er det for enkelte miljøgifter målt en svak nedadgående tendens. Arealet av vernede områder har økt kraftig fra midten av 1970-tallet til i dag.

.....men også negative trekk

På andre områder har utviklingen vært mindre positiv.

Omfanget av støyplager i befolkningen har vært om lag uendret på 1980-tallet. Selv om svovelutslippene er redusert, har økte nedbørsmengder ført til at svovelavsetningene i Norge er om lag uendret etter 1980, mens nitrogenavsetningene har økt.

Forsuringssituasjonen i Norge er derfor ikke bedret, blant annet fordi jordsmonnets motstandskraft mot forsuring i de mest utsatte områdene er redusert. Antall fisketomme innsjøer har økt klart etter 1975. 


\subsubsection{Makroøkonomisk utvikling}

\subsubsection{Makroøkonomisk utvikling}

Fortsatt vekst i norsk økonomi på 1980-tallet, men svakere enn i tiåret før

På lang sikt er det veksten i et lands produksjon av varer og tjenester pr. innbygger som skaper grunnlaget for høyere materielt forbruk. En sammenligning av 1970-tallet og 1980tallet viser at både bruttonasjonalproduktet, disponibel realinntekt for Norge og privat og offentlig konsum fortsatte å vokse på 1980-tallet, men veksttallene var markert svakere enn i tiåret før. Veksten i den disponible realinntekten for Norge var for eksempel 48 prosent fra 1970 til 1980, mot 14 prosent fra 1980 til 1990. Rammene for forbruksutviklingen vokste således sterkere på 1970-tallet enn på 1980-tallet.

Sterkere vekst i offentlig enn i privat konsum I perioden 1970-92 var det en klart sterkere vekst i offentlig konsum enn i privat. Denne utviklingen var særlig markert i perioden 1986-92, hvor privat konsum sett under ett viste en svak nedgang, mens offentlig konsum fortsatte å vokse. Sterk økning i arbeidsledigheten mot slutten av 1980-tallet Utvalget understreker sysselsettingens betydning for levekårene både ved at arbeidskraft er en av våre viktigste produksjonsressurser, ved at sysselsettingsutviklingen spiller en viktig rolle for fordelingen av inntekt og ved at lønnet arbeid er viktig for den enkeltes identitet og sosiale tilhørighet.

Arbeidsledigheten var lav og stabil gjennom 1970-årene og fram til begynnelsen av 1980-tallet. Ledigheten nådde en foreløpig topp i 1983 da antall arbeidss $ø$ kere kom opp i 3,4 prosent av arbeidsstyrken. Ledigheten falt deretter til 2,0 prosent i 1986. Fra 1987 har ledigheten økt til et høyt nivå etter norske forhold, og tallet på arbeidssøkere uten arbeidsinntekt utgjorde 5,9 prosent av arbeidsstyrken i 1992.

Store svingninger i norsk økonomi...

Veksten i norsk økonomi var svakere på 1980-tallet enn på 1970-tallet og svingningene var sterkere. Etter en svak vekst fra 1980 til 1983, var den årlige veksten i bruttonasjonalproduktet $\mathrm{i}$ årene 1983-87 om lag som på 1970tallet. I perioden 1987-92 var produksjonsutviklingen igjen svak, og bruttonasjonalproduktet vokste med vel 1 prosent pr. år i denne perioden.

....ikke minst i privat konsum og investeringer

Svingningene i økonomien fra midten av 1980-tallet og framover har i stor grad sammenheng med utviklingen i privat konsum og investeringer. I perioden 1984-86 økte det private konsumet sterkt, og langt sterkere enn husholdningenes disponible inntekter. Dette ble motsvart av et fall $\mathrm{i}$ husholdningenes sparerate. Husholdningenes ønske om å nedbetale gjeld og høy realrente etter skatt er trolig de viktigste årsakene til at privat konsum falt fra 1986 til 1989. Også i årene 1990-92 har privat konsum vist en svak utvikling i forhold til veksten i husholdningenes disponible inntekter. Investeringene påvirket $\mathrm{i}$ denne perioden norsk økonomi omtrent i samme retning som privat konsum. Fra 1983 til 1987 økte investeringene i fastlands-Norge til et meget høyt nivå. Dette oppsvinget ble avløst av en nedgang fra 1987 til 1992 , både i bedriftenes realinvesteringer og $\mathrm{i}$ husholdningenes boliginvesteringer.

Redusert privat og økt offentlig sysselsetting Fallet i oljeprisen i 1986 førte, sammen med det kraftige innenlandske etterspørselspresset, til en klar svekkelse av 
utenriksøkonomien. For å tilpasse etterspørselen til

inntektsutviklingen for landet etter oljeprisfallet, ble den økonomiske politikken strammet til i årene 1986-88. Den innenlandske etterspørselen avtok betydelig i 1988 og 1989 og i løpet av 1988 ble politikken lagt om i ekspansiv retning. Selv om sysselsettingen i offentlig sektor har økt markert fra 1987 til 1992 har ikke dette veiet opp for nedgangen i sysselsettingen i privat sektor. Dette må blant annet ses i sammenheng med forholdsvis lav internasjonal vekst og etterspørsel etter 1990, og at privat sektor har økt sine finansielle fordringer framfor å øke sin løpende etterspørsel.

Inntektsutviklingen

Utredningen gir oversikt over den samlede inntektsutviklingen. Utvalget anser det også som viktig å gå inn på hvilke forhold som har bidratt til denne utviklingen. Veksten i disponibel realinntekt for Norge kan deles i bidrag fra produksjonsvekst i petroleumssektoren, produksjonsvekst i øvrige næringer, endringer i bytteforholdet overfor utlandet og endringer i rente- og stønadsbalansen overfor utlandet. Fra 1980 til 1990 vokste realdisponibel inntekt for Norge med 14 prosent. Produksjonsvekst i petroleumsvirksomheten og produksjonsvekst i øvrige næringer bidro isolert sett med henholdsvis 11 prosent og 14 prosent vekst. Endringer $\mathrm{i}$ bytteforhold bidro til en nedgang i veksten på 12 prosent, hovedsakelig som følge av oljeprisfallet i 1986.

Produksjonsveksten i øvrige næringer og bytteforholdet overfor utlandet er i betydelig grad påvirket av petroleumssektoren. Denne oppsplittingen gir derfor en god illustrasjon av petroleumssektorens store betydning for inntektsutviklingen $\mathrm{i}$ Norge.

Norges disponible inntekt: Økt andel til husholdningene, redusert andel til det offentlige Husholdningene og offentlig forvaltning har i perioden 1980-91 mottatt mer enn 93 prosent av Norges disponible inntekt. Fra 1980 til 1991 økte husholdningenes andel av Norges disponible inntekt fra 60 prosent til 64 prosent. Andelen som tilfalt offentlig forvaltning ble redusert fra 34 prosent til 29 prosent.

Nedgangen i offentlig forvaltnings andel av landets samlede disponible inntekt kan ikke tas som uttrykk for at forvaltningens betydning i økonomien har blitt redusert gjennom denne perioden. De samlede utgiftene i offentlig forvaltning økte tvert i mot som andel av bruttonasjonalproduktet fra 44 prosent $\mathrm{i}$ 1972, til 48 prosent i 1980 og til 55 prosent i 1991. Når forvaltningens disponible inntekt likevel har vist en fallende andel, skyldes dette at en økende andel av forvaltningens samlede inntekter benyttes til omfordeling ved at de overføres til husholdningene og næringslivet. I tillegg har den offentlige budsjettbalansen blitt kraftig svekket siden midten av 1980-tallet. Offentlige stønader til private konsumenter økte fra 14 prosent av bruttonasjonalproduktet i 1972 til 21 prosent i 1991. Både antall stønadsmottakere og stønad pr. stønadsmottaker vokste. Veksten i antall stønadsmottakere skyldtes blant annet en oppgang i tallet på alders- og uførepensjonister og i antall dagpengemottakere. Økningen i ytelsene pr. stønadsmottaker hadde delvis sammenheng med veksten $\mathrm{i}$ antall pensjonister med rett til tilleggspensjon. 
1.4.4 Tidsbruk, samfunnstilknytning og demografisk struktur 1980 og 1990

1.4.4. Tidsbruk, samfunnstilknytning og demografisk struktur 1980 og 1990

Flere skilte og færre heltidshusmødre....

Alt i alt skjedde det tildels betydelige endringer i den demografiske og samfunnsmessige strukturen i løpet av 1980tallet. Familiemønsteret endret seg og en av de mest påfallende endringene var at tallet på skilte og separerte økte med mer enn 100000 personer. Det var også store endringer i befolkningens tilknytning til arbeidsmarkedet i løpet av tiåret. Antall heltidshusmødre ble redusert fra om lag 480000 til 150 000. På tross av økningen i ledigheten og nedgangen i sysselsettingen etter 1987, var det likevel nesten 100000 flere sysselsatte i 1990 enn i 1980.

....og flere lever av overføringer fra det offentlige Et annet hovedtrekk i utviklingen fra 1980 til 1990 var den økende andel av befolkningen som levde av overføringer fra det offentlige. Både absolutt og relativt økte andelen av befolkningen som ble forsørget gjennom trygde- og omsorgssystemet langt mer enn andelen som var knyttet til andre deler av samfunnssystemet (arbeidsmarked, utdanning og privat forsørgelse). Om lag 920000 mennesker, 22 prosent av hele befolkningen, mottok langtidsytelser fra folketrygden i 1990.

Antall personer under utdanning var omtrent det samme i 1990 som i 1980, i overkant av 800000 .

Tidsbruken endret seg lite på 1980-tallet, når en ser befolkningen under ett. Det ble brukt noe mer tid til inntektsgivende arbeid og til fritidsaktiviteter i 1990 enn i 1980, mens det ble brukt noe mindre tid til husholdsarbeid og personlige behov (søvn, måltider og personlig hygiene).

Kapittel 1 Levekår i Norge. Er graset grønt for alle

1.5 Offentlig tjenesteyting

1.5.1 Offentlig konsum

1.5.2 Det kommunale tjenestetilbudet

1.5.3 Dekningsgrader og ressursunnsats pr. bruker i

pleie-omsorgs-og

undervisningstjenesten

\subsection{OFFENTLIG TJENESTEYTING}

Offentlig tjenesteproduksjon omfatter en rekke ulike ytelser. Utvalget har først og fremst vært opptatt av å beskrive utviklingen i de tjenester som direkte er rettet mot den enkelte brukers velferd, dvs. individuell offentlig tjenesteyting. De viktigste eksempler på dette finner vi innenfor helse, omsorg og undervisning. Det offentlige tjenestetilbudet som er gratis for brukerne og som finansieres gjennom generelle skatter og avgifter, kalles offentlig konsum. Den delen som helt eller delvis dekkes av direkte brukerbetaling eller egenandeler, kalles 
gebyrer. Gebyrene inngår som en del av privat konsum dersom tjenestene benyttes av og direkte finansieres av husholdningssektoren.

\subsubsection{Offentlig konsum}

Sterk vekst

Utvalget konstaterer at det var en sterk realvekst i

offentlig konsum på 1980-tallet, hele 37 prosent. Veksten ble riktignok nesten halvert i forhold til perioden 1970-80, men regnet i faste priser var det offentlige konsumet 130 prosent høyere i 1990 enn 20 år tidligere. Undervisning, helsestell og omsorg (sosial trygd og velferd) utgjorde over 50 prosent av samlet offentlig konsum i 1990. Mens det offentlige konsumet til undervisningsformål vokste svakere enn offentlig konsum i alt både på 1970- og 1980-tallet, var veksttakten for omsorg klart høyere i begge perioder. Etter en relativt sett meget sterk vekst på 1970-tallet vokste offentlig konsum til helseformål om lag i takt med offentlig konsum i alt i det neste tiåret. Det er viktig å være klar over at volumveksten gir utrykk for veksten i ressursbruk og ikke nødvendigvis for økt tjenestetilbud i mengde eller kvalitet.

Velferdskommune Innenfor undervisning, helsestell og omsorg (sosial trygd og velferd) gikk mesteparten av det individuelt rettede offentlige konsumet via kommunene. I 1990 forvaltet kommunene knapt 78 prosent innenfor undervisning, 92,5 prosent innenfor helsestell og nesten 82,5 prosent innenfor omsorg. Andelene vokste på 1980tallet, med unntak for undervisning hvor nedgangen i barnetallet og veksten i studenttallet økte statens andel. Utvikling og drift av offentlige tjenester på områder som omsorg, helse og utdanning er nå i hovedsak kommuners og fylkeskommuners ansvar og 80 prosent av timeverkene i kommuneforvaltningen blir utført på disse områdene. Velferdskommune kan derfor være en bedre beskrivelse av situasjonen enn velferdsstat.

Kraftig vekst i brukerbetalingen for offentlige tjenester

Det var et viktig trekk ved utviklingen på 1980-tallet, særlig fra andre halvdel, at offentlig tjenesteyting vokste sterkere enn offentlig konsum. Motstykket er at en stadig stigende del av tjenestetilbudet ble gitt mot hel eller delvis betaling (gebyrer). Gebyrene som andel av offentlig tjenesteyting ble nesten doblet på 1980-tallet. I 1990 utgjorde gebyrdelen 11,7 og konsumandelen 88,3 prosent av den samlede offentlige tjenesteyting. Mens gebyrandelen i 1990 var 4,2 prosent for undervisning, var den 11 prosent for helse og 20,6 prosent for sosial omsorg.

Noe av gebyrveksten på 1980-tallet skyldtes formelle omlegginger av brukerbetalingsordninger. Selv om en korrigerer for slike administrative omlegginger kan det slås fast at både det absolutte og det relative omfanget av brukerbetaling for offentlige tjenester har økt sterkt på 1980-tallet og videre inn på 1990-tallet. Denne utviklingen har pågått samtidig som det har vært en betydelig vekst i den delen av tjenestetilbudet som stilles fritt til rådighet, målt ved offentlig konsum.

\subsubsection{Det kommunale tjenestetilbudet}

Betydelige ulikheter

Å sikre lik tilgang til og bruk av offentlige tjenester er et sentralt offentlig mål. Det er imidlertid betydelige forskjeller i det samlede tjenestetilbudet mellom primærkommunene, målt som samlede driftsutgifter pr. innbygger. Analyser som utvalget har fått utført tyder på at bare 1/3 av ulikhetene i tjenestetilbudet kan forklares med forskjeller i behovs- og kostnadsfaktorer målt ved befolkningssammensetning, bosettingsstruktur og folketall. 
Ulikhetene synes å være størst innenfor områdene sosialhjelp, kultur og utbygging og minst innenfor undervisning. Helse- og omsorgstjenester kommer i en mellomstilling, men også her er forskjellene betydelige.

Ulikheten i det samlede kommunale tjenestetilbudet økte gjennom første halvdel av 1980-tallet og har holdt seg forholdsvis stabilt deretter. Økt forskjell finner vi innen for områdene administrasjon, kultur og utbygging, mens barnehagetilbudet og utgiftene til sosialhjelp har blitt jevnere fordelt. For helsesektoren og grunnskolen er det stor grad av stabilitet. At ulikhetene på viktige områder var stabile, mens ulikheten i samlede driftsutgifter økte, skyldes at kommuner som hadde et velutbygd tjenestetilbud på ett område i økende grad også fikk god standard på andre områder.

Også ulikheter i tjenestetilbudet fra fylkeskommunene En tilsvarende analyse for fylkeskommunene viser at det er er mindre forskjell mellom fylkeskommuner enn mellom primærkommuner, selv om forskjellen i tjenestetilbudet må karakteriseres som vesentlig. Ulikheten har økt gjennom 1980tallet også for tjenestetilbudet fra fylkeskommunene, men klart mindre enn for primærkommunene.

1.5.3. Dekningsgrader og ressursinnsats pr. bruker i pleie-omsorg- og undervisningstjenestene

Utvalget har sett på ressursinnsats pr. bruker og dekningsgrader i tjenesteytende sektorer som først og fremst yter pleie- og omsorgstjenester eller undervisningstjenester. Utvalget er oppmerksom på at slike mål har store svakheter som mål for virkninger på mottakernes levekår. For eksempel kan økt ressursbruk ha sammenheng med redusert effektivitet, med økt kvalitet eller med et endret behov. Eksempler på det siste er integrering av funksjonshemmende og økt innslag av innvandrere i skolen. For behandlingstjenester er bruken av slike mål såvidt tvilsomme at utvalget har avstått fra å presentere tall for ressursinnsats og dekningsgrad.

Barnehager Barnehagedekningen, målt som antall barnehageplasser pr. barn i alderen 0-6 år økte fra 21 prosent i 1980 til 28 prosent i 1985 og videre til 38 prosent i 1991. Antall barn i barnehage økte i samme periode fra 78000 til vel 150000 . Antall ansatte pr. barn økte fra 0,22 i 1980 til 0,27 i 1991, som tilsvarer 3,8 barn pr. ansatt i 1991. Men dette gjenspeiler ikke en reell standardforbedring, fordi det samtidig har skjedd en sterk økning i barnas gjennomsnittlige oppholdstid og andelen små barn i barnehager.

Grunnskolen og den videregående skole I grunnskolen var antall timeverk utført av undervisningspersonell 3 prosent høyere i 1991 enn i 1980, samtidig som det var 21 prosent eller 120000 færre elever i grunnskolen. Antall undervisningstimeverk pr. elev økte dermed med om lag 30 prosent. I videregående skole har dekningsgraden for aldersgruppen 16-19 år økt fra 49 prosent i 1980 til 64 prosent i 1991, og økningen var særlig sterk etter 1987. Standarden målt ved undervisningstimeverk pr. elev har variert gjennom 1980-tallet, men var i 1991 litt høyere enn i 1980. Universiteter og høgskoler I løpet av 1980-tallet var det en meget sterk vekst i antall studenter. Det samlede studenttall steg fra 82000 i 1981, 95000 i 1985, 137000 i 1990 og nærmet seg 150000 i 1991. Mens det var en nedgang i forholdet elev/lærer i grunnskolen og den videregående skole var det en klar vekst i antall studenter pr. ansatt i universitets- og høgskolesektoren, fra 6,2 i 1981 til 7,5 i 1989. 
Pleie- og omsorgstjenester

Tallet på personer over 66 år økte med 17 prosent fra

1980 til 1991 mens antall personer over 79 år økte med 34

prosent. I samme periode økte antallet institusjonsplasser med ca.

13 prosent. Antall årsverk pr. plass i institusjon økte fra 0,68 i

1980 til 0,84 i 1991. Det var en tilnærmet dobling av årsverkene i

hjemmesykepleien, mens antall årsverk i hjemmehjelpen økte med

19 prosent. Antall hjem som fikk hjemmehjelp gikk opp med 40

prosent, men timetallet hvert hjem fikk i hjemmehjelp gikk ned

fra 171 i 1980 til 142 i 1991.

\section{Kapittel 1 Levekår i Norge. Er graset grønt for alle}

1.6 Økonomiske ressurser

1.6.1 Inntekst

\section{6. $\varnothing K O N O M I S K E ~ R E S S U R S E R$}

\subsubsection{Inntekt}

Vekst i husholdningenes inntekter på 1980-tallet

Utviklingen i inntekt og inntektsfordeling står helt sentralt

i vurderingen av de materielle sider av levekårsutviklingen.

Inntekts- og formuesundersøkelsene, som baserer seg på

representative utvalg av selvangivelser, danner sammen med

nasjonalregnskapet grunnlag for utvalgets vurderinger av

inntektsutviklingen og inntektsfordelingen.

I følge nasjonalregnskapet økte husholdningenes

disponible realinntekt med 17 prosent eller med vel 48 milliarder 1990-kroner fra 1980 til 1990. Som følge av at befolkningen vokste, var veksten i husholdningssektorens disponible realinntekt pr. person noe lavere. Husholdningenes disponible realinntekt pr. person økte med vel 12 prosent fra 1980 til 1990, eller med rundt 9000 1990-kroner. Veksten har fortsatt etter 1990, og foreløpige tall for 1992 indikerer en vekst fra 1990 på rundt 6 prosent.

Sterk stønadsvekst, særlig i de senere år

Den økonomiske og demografiske utviklingen har medført at sammensetningen av husholdningssektorens inntekter har endret seg. Mens utviklingen fram til 1987 særlig var preget av at lønnsinntektene vokste sterkt, var perioden etter påvirket av den svake utviklingen i arbeidsmarkedet, veksten i antallet trygdemottakere og økt finansiell sparing i husholdningene. I 1990 mottok husholdningene vel 44 milliarder 1990-kroner mer i stønader fra offentlig forvaltning enn i 1980. I 1992 hadde dette tallet økt til om lag 57,5 milliarder 1990-kroner. Veksten var særlig sterk etter 1987. Flere alders- og uførepensjonister, og veksten i andelen med tilleggspensjoner, var hovedårsaken. Også økt utbetaling av dagpenger bidro.

Økt sysselsetting ga vekst i lønnsinntektene

fram til 1987

Realverdien av husholdningenes lønnsinntekter var vel 33 milliarder 1990-kroner høyere i 1990 enn i 1980.

Lønnsinntektene vokste sterkt fram til 1987, i hovedsak som

følge av vekst i sysselsettingen. Deretter falt lønnsinntektene i tre år på rad, mest på grunn av nedgang i sysselsettingen. Etter 1990 har reallønnsvekst bidratt til at lønnsinntektene igjen har økt. 
$\varnothing$ kte renteutgifter, men lavere skatt

Husholdningenes netto renteutgifter vokste fram til 1989,

først og fremst som følge av økt gjeld i husholdningene. Veksten var særlig sterk i 1987 og 1988. I årene 1990 til 1992 falt realverdien av netto renteutgifter. Driftsresultatet bidro bare svakt til veksten i husholdningenes disponible inntekter. Betaling av direkte skatter og trygdepremier utgjorde i 1980 i underkant av 25 prosent av husholdningenes samlede inntekter, en andel som i 1990 var falt til vel 22 prosent og i 1992 til vel 21 prosent. Inntekt etter skatt vokste klart raskere enn disponibel inntekt Inntektsstatistikken og nasjonalregnskapet gir samme hovedinntrykk av utviklingen i husholdningenes inntekter gjennom 1980-årene. Det er imidlertid flere måter å måle husholdningenes inntekter på, og utvalget har lagt vekt på å få et bredt bakgrunnsmateriale. Forskjellige inntektsbegreper er derfor brukt i analysene av utvikling og fordeling basert på inntektsstatistikken.

Veksten i husholdningenes renteutgifter har vært sterk gjennom 1980-tallet, i første rekke som følge av økt gjeld. Samtidig fanger inntektsstatistikken bare i begrenset grad opp de fordelene husholdningene har av varige forbruksgoder som bolig, som ofte er finansiert gjennom gjeldsoppbyggingen. På denne bakgrunn har utvalget både sett på inntekt etter skatt og på disponibel inntekt, der gjeldsrenter og skatt er trukket fra samlet inntekt. Mens realveksten i inntekt etter skatt pr. husholdning var om lag 10 prosent fra 1982 til 1990, var veksten knapt 1 prosent når en legger disponibel inntekt til grunn.

Betydelig realinntektsvekst regnet pr. forbruksenhet I vurderingen av levekårsutviklingen for husholdningene må en i tillegg til inntektsutviklingen pr. husholdning ta hensyn til husholdningenes størrelse og sammensetning. Antall personer pr. husholdning har falt fra om lag 2,5 i 1982 til om lag 2,3 i 1990, eller med vel 8 prosent. Når en sammenlikner husholdninger er det imidlertid mye som taler for at en ikke bør la hver person telle likt. Bl.a. vil mange utgifter kunne være lavere pr. person $i$ flerpersonhusholdninger enn i npersonhusholdninger. En måte å sammenlikne inntekter mellom husholdninger på er å regne husholdningsinntekten pr. forbruksenhet, der en gir medlemmene av husholdningene ulik vekt avhengig av alder og antall personer i husholdningene. Basert på et vektsystem utarbeidet av OECD viser beregninger at realveksten i inntekt etter skatt pr. forbruksenhet var om lag 16 prosent fra 1982 til 1990, mens realveksten i disponibel inntekt pr. forbruksenhet var om lag 6 prosent. Realinntektsveksten for en gjennomsnittshusholdning fra 1982 til 1990 ble betydelig høyere når en på denne måten tar hensyn til nedgangen i antall personer pr. husholdning.

Kapittel 1 Levekår i Norge. Er graset grønt for alle 1.6.2 Inntekstfordeling

\subsubsection{Inntektsfordeling}

Minst variasjon når en ser på disponibel inntekt pr. forbruksenhet Utvalget har analysert inntektsfordelingen både ved å regne inntekt pr. husholdning, og ved å regne husholdningenes inntekter pr. forbruksenhet. Inntekt etter skatt var jevnere fordelt enn samlet inntekt, og disponibel inntekt varierte mindre enn 
inntekt etter skatt. Inntektsfordelingen blir jevnere når en regnet husholdningenes inntekter pr. forbruksenhet. Dette reflekterer at husholdningene med høyere inntekter i større grad består av flere personer enn husholdningene med lavere inntekter.

Omtrent den samme inntektsfordeling i 1982 og 1990....

Hovedinntrykket er at inntektsfordelingen holdt seg

relativt stabil fra 1982 til 1990. Dette gjelder både fordelingen av inntekt etter skatt og disponibel inntekt. Det har vært en viss tendens til skjevere fordeling mellom husholdningene fra 1982 til 1990, men denne tendensen forsvinner langt på vei når en tar hensyn til endringene i husholdningenes størrelse og sammensetning ved å regne inntektene pr. forbruksenhet. .....men tendens til økt ulikhet mot slutten av 1980-tallet Selv om stabiliteten $\mathrm{i}$ inntektsfordelingen har vært stor når en ser 1980-tallet under ett, skjedde det likevel endringer som avspeiler de store svingningene i norsk økonomi gjennom perioden. I perioden 1982-86 var det tegn til en jevnere inntektsfordeling, men denne utviklingen snudde. I andre halvdel av 1980-tallet økte forskjellene igjen svakt. Tendensen til jevnere fordeling fram til midten av 1980-tallet må bl.a. ses i sammenheng med veksten i sysselsetting i denne perioden. Yrkesaktiviteten blant kvinner økte, og reduserte antallet ninntektshusholdninger. En viktig faktor bak tendensen til større ulikhet mot slutten av 1980-tallet var utviklingen på

arbeidsmarkedet.

Svakheter i datamaterialet

En viktig svakhet ved det datamaterialet utvalget har hatt tilgang til i analysen er at det i bare begrenset grad fanger opp kapital- og næringsinntekter med helt eller delvis skattefritak. Eksempler på slike inntekter er gevinster og tap ved kjøp og salg av formuesobjekter. Utviklingen i slike uregistrerte inntekter var mye omtalt på 1980-tallet. Den svake tendensen til utjevning fram til 1986, som i følge vårt datamateriale ser ut til å ha blitt avløst av en utvikling med noe økte forskjeller, kan ha sin bakgrunn i slike mangler. Inntektsvekst for de aller fleste grupper Når en inndeler husholdningene i hovedgrupper som enslige, par med og uten barn samt enslige forsørgere, hadde alle grupper bortsett fra enslige under 45 år høyere realinntekt etter skatt i 1990 enn i 1982. Realveksten i inntekt etter skatt var sterkest for par med barn, samt par uten barn i alderen 45-64 år (etter hovedinntektstakers alder). Alle grupper hadde en svakere realinntektsvekst når en trekker fra gjeldsrenter, men gjeldsrentene hadde liten betydning for husholdningene med de eldste hovedinntektstakere.

Lønnsinntekter, næringsinntekter og kapitalinntekter bidro til ulikhet....

Både lønnsinntekter, næringsinntekter og kapitalinntekter var gjennomgående høyere desto høyere det samlede inntektsnivået $\mathrm{i}$ husholdningene var.

....men overføringene virket utjevnende

Overføringene viste en motsatt tendens og var den eneste inntektsarten som hadde en direkte utjevnende effekt.

Overføringene utgjorde en større andel av inntektene for gjennomsnittshusholdningen i 1990 enn i 1982, og andelen har gjennom 1980-årene særlig økt for husholdningene med lavere inntekter. Når overføringene etterhvert spiller en større rolle for husholdningene på lavere inntektsnivåer, reflekterer dette i stor grad at det har blitt flere pensjonister. Dagpenger og sykepenger er ikke regnet som overføringer i inntektsstatistikken, men som lønnsinntekt.

Lønnsinntektene utgjorde en mindre andel av husholdningenes samlede inntekter i 1990 enn i 1982, og andelen falt mest for husholdninger med lav inntekt. Dette må ses i sammenheng med veksten i arbeidsledigheten. 
Skatter er proporsjonale over et visst inntektsnivå for husholdninger

Skatt utgjør en mindre andel av inntektene på de lavere inntektsnivåene enn de høyere, men for husholdningsinntekter som overstiger 175-200 $000 \mathrm{kr}$ stiger skatten mer i takt med husholdningenes inntekter slik de er definert i inntektsstatistikken. Dette må dels ses i sammenheng med at mange husholdninger består av en inntektstaker med høy og en med lav inntekt, og dels at den formelle progresjonen i skattesystemet har blitt dempet gjennom fradragsordninger som særlig har kommet inntektstakere på høyere inntektsnivåer til gode.

Skattereformen 1992 og inntektsfordelingen

Som følge av de omfattende endringene som ble gjennomført i skattesystemet for inntektsåret 1992, knytter det seg særlig stor interesse til om det har skjedd endringer i inntektsfordelingen i 1992.

Det foreligger imidlertid ikke inntektsstatistikk for 1992, og en har derfor et mangelfullt grunnlag for å vurdere hva som har skjedd med inntektsfordelingen dette året. Skattereformen vil både ha indirekte virkninger på inntektsfordelingen, ved at den påvirker inntektene før skatt, og direkte virkninger, gjennom hvor mye skatt den enkelte betaler av sin inntekt før skatt. Skattereformen er av en slik karakter at de indirekte virkningene på inntektsfordelingen kan være betydelige. Det en på det nåværende tidspunkt har mulighet for å si noe om, er i hovedsak den direkte virkningen av endringene i satser og beløpsgrenser fra 1991 til 1992. Slike virkninger er under forenklede forutsetninger om utviklingen i inntekter og fradrag belyst av Det tekniske beregningsutvalget for inntektsoppgjørene. Disse beregningene indikerer at fordelingen av skatt etter inntektsnivå i hovedtrekk er de samme i 1992 som i 1991. Utvalget vil imidlertid understreke at disse beregningene ikke har som formål å belyse hva som er skjedd med inntektsfordelingen i 1992, men er ment å illustrere hvordan endringene i enkelte viktige skattregler isolert sett bidrar til utviklingen i inntekt etter skatt.

Kapittel 1 Levekår i Norge. Er graset grønt for alle 1.6.3 Inntekstutvikling 1982-90 for ulike fødselskull

\subsubsection{Inntektsutvikling $1982-90$ for ulike fødselskull}

Datamaterialet fra inntektsundersøkelsene 1982, 1986 og 1990 er benyttet til å se nærmere på generasjonseffekter i perioden 1982-90. Analysen er basert på en relativt grov inndeling av utvalget for hvert av de tre undersøkelsesårene i tiårs fødselskull, såkalte ti-årskohorter. Det eldste tiårs fødselskullet ble født i årene 1911-20, det yngste i årene 196170.

Inntektsutviklingen for personer: De yngre fødselskull er bedre stilt enn de eldre var på samme alderstrinn

Alle fødselskull som er født etter 1940 (dvs. de som var under 42 år i 1982 og under 50 år i 1990), hadde en positiv utvikling i personlig inntekt (målt i faste kroner) i perioden. Dette gjaldt både menn og kvinner, og både samlet inntekt og inntekt etter skatt. 
Utviklingen for de eldre fødselskullene ble imidlertid stadig sterkere preget av overgang til pensjoniststatus, med nedgang i gjennomsnittlig samlet inntekt med økende alder. Det var relativt beskjeden endring i det gjennomsnittlige inntektsnivået for mellomgenerasjonene født 1931-40. Det var en positiv utvikling over tid når vi sammenlikner yngre og eldre fødselskull. Yngre fødselskull hadde en høyere gjennomsnittlig realinntekt i 1990 enn eldre hadde i 1982 på sammenlignbare alderstrinn.

Kvinner hadde fortsatt betydelig lavere inntekt enn menn, også når det tas hensyn til at kvinner mottar barnetrygd og andre overføringer i større grad enn menn. Det var en svak reduksjon i de relative inntektsforskjellene i perioden.

Kapitalinntekter og overføringer får økt betydning med stigende alder

Andelen som har overføringer som viktigste inntektskilde $ø$ øer med alderen. Før pensjonsalder er det kvinner som mottar mest overføringer, og det er langt flere kvinner enn menn som har overføringer som sin viktigste inntektskilde. Det er imidlertid mennene som i gjennomsnitt mottar de største årlige ytelsene fra folketrygden etter at de blir pensjonister. Samtidig mottar kvinner i gjennomsnitt ytelser i flere år.

Det er få som har kapitalinntekt som viktigste inntektskilde, men kapitalinntekten får økende betydning med alder. For menn født i tidsrommet 1911-20 utgjorde gjennomsnittlige brutto kapitalinntekter i 199028300 kroner. Dette tilsvarer 21 prosent av disse mennenes gjennomsnittlige bruttoinntekt i 1990. I denne aldersgruppen utgjorde kvinnenes gjennomsnittlige kapitalinntekter 11800 kroner i 1990, eller 14 prosent av disse kvinnenes bruttoinntekt. Forskjellen mellom kvinner og menn er i noen grad påvirket av reglene for ektefellebeskatning.

Gjeldsrenter: Alle fødselskull, bortsett fra de eldste, utnyttet de bedrede lånemulighetene midt på 1980-tallet Utviklingen i husholdningenes disponible realinntekt på 1980-tallet ble sterkt påvirket av endringer i gjeld og rentenivå. Det var husholdningene hvor referansepersonene er født mellom 1951-60 som hadde den sterkeste økningen i rentebelastningen i perioden, enten den måles i faste kroner eller som prosent av husholdningens samlede inntekt. I 1990 var de gjennomsnittlige renteutgiftene på husholdningsnivå for disse fødselskullene 65 000 kroner, og utgjorde 18,8 prosent av husholdningens gjennomsnittlige samlede inntekt. Det var imidlertid ikke bare husholdningene i den utpregede etableringsfasen som benyttet seg av de bedrede lånemulighetene og det deregulerte kredittmarkedet fra midten av 1980-tallet. Med unntak av personer født i tidsrommet 1911-20 var det en markert økning i den gjennomsnittlige rentebelastningen i perioden 1982-86 i alle kohortene.

Forskjellene mellom de to yngste aldersgruppene og de eldre gir seg først og fremst utslag $i$ at de eldre fødselskullene stabiliserte de gjennomsnitt- lige renteutgiftene på 1986-nivået fram til 1990. I et mer fullstendig bilde av effekten av gjeldsrenter, må en ta hensyn til den kombinerte effekten av renteutgifter og skatt. For gjennomsnittlig disponibel inntekt, dvs. hva husholdninger totalt sett har å rutte med etter at renter og skatt er trukket fra, var det liten variasjon etter livsfase. Den samlede effekten av renteutgifter og skatt var m.a.o. at den bidro til å utjevne forskjeller i disponibel inntekt mellom livsfaser og fødselskull. 
Kapittel 1 Levekår i Norge. Er graset grønt for alle

1.6.4 Inntekstmoblilitet 1986-90

1.6.5 Formue og formuesfordeling

\subsubsection{Inntektsmobilitet $1986-90$}

Meget lav inntektsmobilitet

En analyse av individuelle selvangivelser for årene 1986-

90 (paneldata, der en følger et utvalg av husholdninger over flere år), viser at personer med lave inntekter i 1986 gjennomgående hadde lave inntekter i de påfølgende fire årene. Tilsvarende hadde personer med høye inntekter i 1986 også høye inntekter i årene 1987-90. Bak den lave inntektsmobiliteten skjuler det seg en tydelig stabilitet i personers tilknytning til arbeidsmarkedet. $A v$ de personer som var 17 år og over i 1986 var 25 prosent aldri yrkesaktive i årene fram til 1990 . Ca. 70 prosent av de som aldri var yrkesaktive tilhørte de 30 prosent med lavest inntekt. Blant de 10 prosent med høyest inntekt var 95 prosent hele tiden yrkesaktiv, mens ingen blant de 10 prosent med lavest inntekt var yrkesaktiv i mer enn 3 år i løpet av 5-årsperioden 1986-90.

\subsubsection{Formue og formuesfordeling}

Svakt metodisk og statistisk grunnlag for vurderingen Det er en rekke metodemessige problemer med analyser av formuesfordelingen. Sammenhengen mellom fordelingen av formue og velferd kan være mer uklar enn sammenhengen mellom inntekt og velferd. Yngre aldersgrupper kan ønske å oppta lån for å øke sin velferd ut fra forventninger om høyere inntekter senere i livet. Dette kan gi opphav til skjev formuesfordeling mellom ulike aldersgrupper, men være et resultat av en tilpasning som er ønskelig og et velferdsmessig gode for den enkelte.

Det er en rekke svakheter ved de tilgjengelige formuesdataene som gjør at utvalget finner det vanskelig å trekke omfattende konklusjoner om formuesfordelingen.

Skatteligningen er den viktigste kilden for tallene. Som følge av at ligningsverdien legges til grunn undervurderes markedsverdien for flere formuesobjekter, blant annet for boliger.

Formuen synes å være svært ulikt fordelt

Tallene basert på opplysninger fra skatteligningen, kan imidlertid tyde på at formuen er svært ulikt fordelt mellom husholdningene. I 1990 disponerte de 10 prosent av husholdningene som hadde størst formue, mer enn halvparten av samlet formue. Dersom ligningsverdiene for realkapitalen erstattes med opplysninger om antatt markedsverdi, blir formuen jevnere fordelt, men er fortsatt betydelig skjevere fordelt enn inntekten. Det mangler imidlertid tilsvarende opplysninger om andre formuesgjenstander, slik at det ikke kan trekkes noen slutninger om hvordan formuesfordelingen ville vært med en komplett registrering.

Nettofinansformue: Negativ for de yngste, positiv for de eldste husholdningene

De yngste husholdningene har negativ nettofinansformue, mens den er positiv i de eldste husholdningene. Dette er et trekk som ble forsterket gjennom 1980-årene. De yngste

husholdningene reduserte sin finansformue kraftig fra 1982 til 1990. I husholdninger der hovedinntektstakeren var over 66 år, $ø$ øte gjennomsnittlig nettofinansformue nominelt sett med om lag 100000 kroner fra 1982 til 1990. Jamt over hadde de 
husholdningene som hadde høyest inntekt i gjennomsnitt også størst bruttofinansformue og gjeld.

De fleste har en håndterlig gjeld...

Tall fra inntekts- og formuesstatistikken tyder på at de

aller fleste husholdninger har en gjeld som er tilpasset inntektene.

I 1990 hadde 86 prosent av husholdningene en gjeld som var

mindre enn to ganger husholdningenes inntekt før skatt. I 1982

var den tilsvarende andelen 93 prosent.

....mens enkelte har mye gjeld $i$ forhold til inntekten

5 prosent av husholdningene hadde en gjeld som var større enn tre ganger inntekten i 1990. Andelen husholdninger med høy gjeld i forhold til inntekten var størst blant de 25

prosent av husholdningene med høyest inntekt pr. forbruksenhet. Mange misligholder lån

Anslag fra 1991 antyder at 120000 husholdninger misligholdt ett eller flere lån. Faren for at en husholdning hadde betalingsproblemer avtok som en skulle vente, med størrelsen på inntekten og økte med størrelsen på gjelda. Andre anslag viste at om lag 60000 husholdninger misligholdt ett eller flere lån på 50 000 kroner eller mer. 15-20 000 av disse husholdningene misligholdt lån på over 250000 kroner.

På bakgrunn av disse tallene kan en ikke slutte om betalingsproblemene skyldes høy gjeld eller lav inntekt. Tallene sier heller ikke noe direkte om antall gjeldsbelastede husholdninger som har tapt sin egenkapital og som har blitt nødt til å realisere tapet. Beregningene viser imidlertid klart at mange har alvorlige betalingsproblemer.

Arv og gaver

Mangel på regelmessig statistikk har gitt utvalget svært begrenset grunnlag for å vurdere hvilken betydning arv og gaver har for levekårene. Enkelte undersøkelser kan imidlertid tyde på at aldersgruppen 40-49 år i gjennomsnitt mottar mest i arv og gaver. Det er også indikasjoner på at andelen som oppgir å ha mottatt arv og gaver og gjennomsnittsverdien av det de har mottatt, stiger med husholdningenes inntekt.

Kapittel 1 Levekår i Norge. Er graset grønt for alle 1.6.6 Forbruksutviklingen på 1980-tallet

\subsubsection{Forbruksutviklingen på 1980-tallet}

Utviklingen i privat konsum beskrives noe forskjellig i nasjonalregnskapet og i forbruksundersøkelsene. Begge viser imidlertid sterk vekst på 1980-tallet fram til 1986 og deretter nedgang. For perioden 1982-90 viser nasjonalregnskapet en vekst i privat konsum pr. innbygger på 13 prosent regnet i faste priser. I følge forbruksundersøkelsene er de tilsvarende vekstrater 31 prosent, altså en vesentlig sterkere vekst. En viktig forskjell mellom de to kildene knytter seg til boutgift som er forskjellig definert. Forbruksundersøkelsene viser om lag dobbelt så stor vekst i disse som nasjonalregnskapet.

Vekst i boutgiftene Boutgiftenes andel av totalforbruket økte i følge forbruksundersøkelsene fra 18 til 27 prosent i perioden 1980-82 til 1989-91. Utgiftene til reiser og transport, herunder kjøp av bil, utgjorde 19 prosent av totalforbruket i 1989-91. Andelen har ikke økt siden begynnelsen av 1980-tallet, men økte fram til 
1986-88 for deretter å avta.

Høyest forbruksvekst for middelaldrende par uten barn og pensjonister

I følge forbruksundersøkelsene var middelaldrende par uten barn sammen med pensjonister, både enslige og par, de grupper som hadde relativt sett den største forbruksveksten på 1980-tallet. Veksten var 35-40 prosent fra perioden 1980-82 til 1989-91 regnet i faste priser. Pensjonistenes forbruk økte jevnt gjennom tiåret, og var i liten grad preget av den særlig sterke forbruksveksten midt på 1980-tallet. Enslige under pensjonsalder hadde en svakere forbruksutvikling. Fra 1980-82 til 1989-91 økte forbruket for yngre enslige med vel 25 prosent, mens det for middelaldrende enslige økte med 15 prosent (regnet i faste priser). Disse enslige fikk del i forbruksveksten midt på 1980tallet, men opplevde som gruppe den sterkeste innstramning $\mathrm{i}$ forbruket etter 1986-88.

Kapittel 1 Levekår i Norge. Er graset grønt for alle

1.7 Utdanning

1.7.1 Strukturendringer i utdannigssystemet

1.7.2 Kjønnsfordeling og regional utvikling

1.7.3 Arbeid og utvikling

\subsection{UTDANNING}

Utvalget har vært spesielt opptatt av forholdet mellom skole og arbeidsliv fordi det de senere år har vært store problemer på arbeidsmarkedet, og særlig for ungdommen. I tillegg har utvalget vært opptatt av hvorvidt avkastningen av utdanning, i form av gode jobber og/eller i form av god inntekt, har endret seg. Utdanning er også en levekårskomponent med egenverdi.

1.7.1. Strukturendringer i utdanningssystemet

Store endringer

Strukturen i utdanningssystemet endret seg på 1980-

tallet. Elevtallet i den kommunale grunnskolen ble redusert fra 584000 i 1981/82 til 462000 i 1991/92, elevtallet i videregående skole (under lov om videregående skole) økte fra snaut $160000 \mathrm{i}$ 1981/82 til vel 200000 i 1991/92 og studenttallet ved universiteter og høgskoler økte i samme periode fra 82000 til snaut 150 000. Antallet studenter og skoleelever er dermed omtrent det samme i dag som i begynnelsen på 1980-tallet, men fordelingen på skoleslag er drastisk endret.

Nesten alle grunnskoleelever går nå direkte over i videregående utdanning For grunnskolen avspeiler dette naturligvis en reduksjon i årskullenes størrelse. Veksten i antallet elever/studenter i videregående skole og ved universiteter og høgskoler har nær sammenheng med den vanskelige arbeidsmarkedssituasjonen mot slutten av 1980-tallet. Mens vel 80 prosent av grunnskoleelevene gikk direkte over i videregående utdanning i 1980 gjaldt dette for 95 prosent av grunnskoleelevene i 1991. Arbeidsmarkedet er i svært liten grad noe alternativ til videre utdanning etter grunnskolen. Heller ikke for alle avgangselever fra videregående skole er arbeidsmarkedet lenger et alternativ, og dette, i tillegg til en vekst i årskullenes størrelse, har ført til økningen i

studenttallet. 
Det er fortsatt sosiale, kjønnsmessige og geografiske forskjeller i rekruttering til videregående utdanning. Vi har ikke opplysninger om grunnskoleelevenes sosiale bakgrunn etter 1980. Likevel er det grunn til å tro at det også ti år senere finnes systematiske ulikheter både $i$ valg av studieretning og $i$ valg mellom videre utdanning og arbeidsliv. I 1980 var hovedtendensen at barn fra høyeste sosialgruppe i langt større grad valgte allmennfaglig studieretning, og at de i mye mindre grad avsluttet utdanningen etter grunnskolen enn barn fra den laveste sosialgruppen.

1.7.2. Kjønnsfordeling og regional utvikling

Flere jenter enn gutter velger en studieretning etter grunnskolen som gir generell studiekompetanse....

Det er fremdeles betydelige forskjeller mellom jenter og gutter i valg av studieretning etter grunnskolen. Halvparten av de kvinnelige avgangselevene fra grunnskolen i 1991 valgte allmennfaglig studieretning, mot en tredjedel av guttene. Jenter er overrepresentert innenfor helsefag og estetiske fag, mens guttene er overrepresentert innenfor håndverks- og industrifag. Når vi tar hensyn til at også handels- og kontorfag gir studiekompetanse valgte 70 prosent av jentene, mot 50 prosent av guttene en studieretning som gir generell studiekompetanse. Guttene er derimot i flertall innenfor fagopplæringen.

....og også på universitets- og høgskolenivå er valg av fagfelt svært ulikt for kvinner og menn

Det har vært en større økning i studietilbøyelighet blant kvinner enn blant menn. Antallet kvinnelige studenter har økt med over 70 prosent $\mathrm{i}$ løpet av perioden 1981-89. Tilsvarende blant menn var 40 prosent.

Også på universitets- og høgskolenivå er valget av fagfelt svært ulikt for jenter og gutter. Det er ingen sterk tendens til at kjønnsforskjellene i valg av fagfelt er blitt mindre i løpet av 1980årene, selv om kvinner nå har et bredere valgspektrum enn tidlig på 1980-tallet. De har også et mer variert utdanningsmønster enn menn. En kan kanskje si at kvinner i en viss utstrekning velger mer "kjønnsnøytralt" i dag enn for ti år siden, mens menns studievalg i liten grad er blitt endret. I 1981 utdannet nesten halvparten av de kvinnelige studentene seg innen helsevern og undervisning. I 1989 var denne andelen redusert til ca. 1/3. På høyere nivå utdanner mennene seg innenfor få fagfelt, mens kvinnene fordeler seg mer jevnt på flere. På lavere nivå er imidlertid også kvinnene konsentrert på få fagområder.

Regional utjevning av studiefrekvensen

Andelen av et årskull som fullfører videregående

utdanning har økt stekt i alle landsdeler fra $1950 \mathrm{og}$ fram til idag, men den er fortsatt høyest i Oslo og Akershus. Finmark har den laveste andelen. Også når det gjelder studiefrekvensen er hovedtendensen de siste ti årene at det har foregått en utjevning mellom fylkene. Utbyggingen av de regionale høgskolene har antakelig ført til en bredere og jevnere geografisk rekruttering til høyere utdanning.

Sterke kapasitetsbegrensninger på praktiske linjer

Kapasitetsbegrensninger på praktiske linjer i videregående skole påvirker fullføringsgraden. En av tjue elever som begynte på håndverks- og industrifag etter grunnskolen fullførte 12. klassetrinn på normert studietid. Av de som begynte på allmennfaglig linje gjaldt det rundt åtte av ti elever.

Sterk økning i utdanningsnivået i befolkningen Vi har fått en høyere utdannet arbeidskraft i løpet av 1980-tallet. Blant de sysselsatte er det blitt 200000 færre med bare grunnskoleutdanning og 200000 flere med universitets- og høgskoleutdanning. Dette skyldes naturlig nok at eldre med lav utdanning forlater arbeidsmarkedet og blir erstattet av yngre med 
betydelig høyere utdanning.

\subsubsection{Arbeid og inntekt}

Utdanning har fått økt betydning for den enkeltes mulighet til arbeid....

Utdanning vil normalt øke den enkeltes

sysselsettingsmuligheter. Dette er kanskje særlig viktig i perioder med stor arbeidsledighet. Utdanningens betydning for å få arbeid ser ut til å ha økt gjennom 1980-tallet, og ser ut til å ha økt mer for menn enn for kvinner. 69 prosent av befolkningen i alderen 16-74 år var med i arbeidsstyrken i 1990. Med arbeidsstyrken menes sysselsatte og arbeidsledige. 86 prosent av de universitetsog høgskoleutdannede i den aktuelle aldersgruppen inngikk i arbeidsstyrken i 1990, mot bare 49 prosent av 16-74 åringene med utdanning på ungdomsskolenivå. Og for menn med bare grunnskoleutdanning ble andelen i arbeidsstyrken redusert i så godt som alle aldersgrupper i løpet av 1980-tallet, men mest for de eldste. Blant menn med høyere utdanning ble andelen $\mathrm{i}$ arbeidsstyrken bare redusert blant 60-66 åringer, men fortsatt var 75 prosent av disse mennene med i arbeidsstyrken i 1990. Arbeidsledigheten varierte også med utdanningsnivå. Ledigheten var høyest blant personer med lavest utdanning. Den relative økningen i arbeidsledigheten på 1980-tallet var størst blant sysselsatte med utdanning på universitets- og høgskolenivå.

....men noe redusert betydning for inntektsnivået.

Det er klar sammenheng mellom utdanning og inntekt, men inntektsforskjellene mellom utdanningsgruppene er blitt mindre. I 1970 hadde personer med bare kort allmennutdanning (folkeskole, framhaldsskole, grunnskole eller folkehøyskole) under halvparten så høy inntekt som personer med embetseksamen. I 1990 var forskjellen noe mindre, men likevel klar. Størst inntektsøkning finner vi imidlertid blant de med lavest utdanning. Inntektsspredningen mellom utdanningsgruppene er også gått ned fra 1970 til 1990. Det ser derfor ut til at utdanningens betydning for inntekt isolert sett har gått noe ned. På den annen side har utdanning etterhvert blitt en viktigere forutsetning for å få inntektsgivende arbeid.

Unge med lav utdanning har fått det verre gjennom 1980-tallet Unge med lav utdanning stiller svakere på arbeidsmarkedet enn annen ungdom, og denne gruppen fikk det verre gjennom 1980-tallet. Mens ungdom flest har kompensert for dårligere vilkår på arbeidsmarkedet med skolegang, har denne gruppen en høyere andel ledige, særlig med lengre ledighet. Lav utdanning gir generelt jobber med lav status, dårlig arbeidsmiljø og lav lønn. Lav lønn betyr også en vanskelig $ø$ øonomisk situasjon generelt, og større avhengighet av sosialhjelp enn annen ungdom.

Ungdommene med lav utdanning ble hardere rammet av lavkonjunkturene mot slutten av 1980-tallet enn ungdom flest. Konsekvensene av å ha lav utdanning er sannsynligvis alvorligere enn tidligere, etterhvert som kvalifikasjonskravet i arbeidslivet generelt øker.

Kapittel 1 Levekår i Norge. Er graset grønt for alle 1.8 Arbeidsmarkedet

1.8.1 Sysselsetting og arbeidsledighet

1.8.2 Næringsstruktur og regional fordeling 


\subsubsection{Yrkesaktivitet}

1.8.4 Kjønnsroller på arbeidsmarkedet

\subsection{ARBEIDSMARKEDET}

Hvorvidt en har arbeid eller ikke betyr svært mye for den enkeltes levekår. Utviklingen på arbeidsmarkedet er derfor av sentral betydning når levekårsutviklingen på 1980-tallet skal beskrives. 1980-tallet var preget av uro og svingninger på arbeidsmarkedet. Inntektsgivende arbeid ble et knapt gode mot slutten av 1980-tallet, og et gode som var skjevt fordelt mellom ulike grupper. De som ble stengt ute fra arbeidsmarkedet var $\mathrm{i}$ første rekke de unge og de eldre. Dette betydde igjen at andre arenaer ble viktigere for disse gruppene enn de hadde vært tidligere; utdanning for de unge, trygdeordninger for de eldre. I tillegg ble inntektssikring gjennom sosialhjelp viktigere for en del av dem som falt utenfor i konkurransen om jobbene.

1.8.1. Sysselsetting og arbeidsledighet

Ustabilt arbeidsmarked og flere ledige

1980-tallet kan deles inn i tre perioder:

1980-84: I denne perioden økte tallet på sysselsatte

personer med 62 000. Kvinner stod for hele denne økningen. I

forhold til 1980 ble arbeidsledigheten fordoblet til knapt 3,5

prosent under lavkonjunkturen i 1983-84.

1984-87: I denne perioden var det kraftig vekst i

etterspørselen etter arbeidskraft, og arbeidsledigheten sank til under 2 prosent. Sysselsettingen økte med omlag 160000 personer, hvorav 100000 kvinner.

1987-92: Etter 1987 forverret situasjonen på

arbeidsmarkedet seg kraftig fra år til år. Tallet på sysselsatte gikk ned med 122 000, hvorav 98000 var menn. Ledigheten økte, og i 1992 var tallet på arbeidssøkere uten arbeidsinntekt 126000 personer, dvs. knapt 6 prosent av arbeidsstyrken.

Sysselsettingsreduksjonen rammet først og fremst menn og mannsdominerte næringer, og det var i første rekke heltidsarbeidsplasser som gikk tapt.

Arbeidsledigheten rammer ulike grupper forskjellig Arbeidsledigheten blant menn er nå høyere enn blant kvinner. Dette har sammenheng med at lavkonjunkturen har rammet de mannsdominerte næringene hardest. Unge og eldre er særlig rammet av nedgangen i arbeidsmarkedet. Videre er ledighetsnivået høyest blant personer med lav kompetanse, men ledigheten har økt mest blant personer med høy utdanning.

Det er også geografiske variasjoner i ledigheten. Men fordi myndighetene har satset sterkt på arbeidsmarkedstiltak i de fylkene som tradisjonelt har vært hardt rammet av arbeidsledighet er ledigheten nå mindre skjevt fordelt enn under forrige lavkonjunktur. For eksempel er det flest på tiltak i Nord-Norge. Storbyledigheten har økt, og i 1991 var den registrerte ledigheten høyere i Oslo enn landsgjennomsnittet.

1.8.2. Næringsstruktur og regional fordeling

Næringsstrukturen endret seg betydelig i løpet av 1980-

tallet. Nedgangen $i$ industrisysselsettingen og i sysselsettingen $i$ primærnæringene fortsatte. Tallet på sysselsatte i offentlig forvaltning økte med 25 prosent (115 000) fra 1980 til 1990. Problemene på arbeidsmarkedet har slått ulikt ut i ulike regioner. Oslo har hatt den svakeste utviklingen i antall arbeidstakere. Også resten av Østlandet hadde en nedgang i antallet 
arbeidstakere. Det er særlig industrisysselsettingen som har sunket. Nedgangen i industriarbeidsplasser har slått sterkest ut for Oslo og for Nord-Norge. Fra 1985 til 1991 mistet Oslo en femtedel og Finnmark en tredjedel av sine industriarbeidsplasser. 1.8.3. Yrkesaktivitet

Økt yrkesaktivitet blant kvinner....

Kvinnesysselsettingen fortsatte å øke på 1980-tallet, og yrkesfrekvensen for kvinner nærmer seg yrkesfrekvensen for menn. Samtidig ble flere kvinner yrkesaktive på heltid. Det er særlig småbarnsmødre som økte sin yrkesaktivitet, og økningen var størst blant dem med to eller flere barn. Og selv om det fortsatt er slik at mødres yrkesaktivitet stiger med barnas alder, ble forskjellene mindre på 1980-tallet.

....og yrkesaktiviteten øker med utdanningsnivået

Utdanningsnivået har fått økende betydning både for menns og kvinners yrkesdeltakelse. Likevel er det fortsatt slik at utdanning betyr mer for kvinner enn for menn, selv om forskjellen er redusert.

Sterk forverring på arbeidsmarkedet for de unge....

Lavkonjunkturen på arbeidsmarkedet har som nevnt slått sterkt ut blant ungdommen. Ungdom som forlater grunnskolen, har nå i stor grad valget mellom utdanning og arbeidsledighet. Selv med den store tilstrømmingen til utdanningssystemet, utgjorde ungdom i alderen 16-24 år noe over en tredjedel av de arbeidsledige i 1991. 12,8 prosent av 16-24 åringene som inngikk i arbeidsstyrken var arbeidsledige, mot 5,5 prosent i hele den yrkesaktive befolkningen. Videre rammes ungdommen ofte av langtidsledighet, dvs. ledighet som varer over et halvt år. En fjerdedel av de registrerte arbeidsledige ungdommene i alderen 20-29 år var langtidsledige i 1991. Gjennomsnittlig ledighetsperiode var 38 uker.

....og for de eldre

Arbeidsmarkedet for de eldre er også vanskeligere.

Førtidspensjonering i form av uførepensjon har økt, både for kvinner og menn. Menn som er 50 år og eldre har i en årrekke redusert sin yrkesaktivitet. Den største reduksjonen finner vi i årene rett før pensjonsalderen (65-66 år) der yrkesfrekvensen gikk ned fra 63 til 42 prosent det siste tiåret. I tillegg til at flere eldre går ut av arbeidsstyrken, rammes de ofte av langtidsledighet. Om lag halvparten av de arbeidsledige over 50 år var langtidsledige i 1991. Situasjonen for de eldre preges altså dels av en avgang fra arbeidsstyrken og over på uførepensjon eller ordinær førtidspensjonering, dels av høy andel langtidsledige.

Høyest ledighet blant innvandrere fra den tredje verden Innslaget av utenlandske arbeidstakere har økt. En av tjuefem arbeidstakere i Norge er innvandrer. Snaut halvparten av disse kom fra et skandinavisk land eller fra Storbrittania, Tyskland eller USA i 1991, mot vel halvparten i 1987. Andelen arbeidstakere fra Asia, Afrika og Latin-Amerika (den tredje verden) og fra Øst-Europa har dermed økt.

Det har vært større nedgang i sysselsettingen blant innvandrere enn blant nordmenn, men arbeidsmarkedsproblemene har rammet de ulike innvandrergruppene forskjellig, De nordiske innvandrerne kommer best ut, mens andelen sysselsatte har gått mest ned blant innvandrerne fra den tredje verden og fra Øst-

Europa.

Andelen arbeidsledige varierer sterkt med statsborgerskap. Blant nordiske statsborgere utgjorde de arbeidsløse 4,2 prosent av arbeidsstyrken i 1991 mens statsborgerne fra den tredje verden skilte seg ut med en markert høyere ledighet ( om lag 18 prosent). I 1991 var to av tre arbeidsløse utlendinger fra disse landene.

\subsubsection{Kjønnsroller på arbeidsmarkedet}


Fortsatt tradisjonelle kjønnsroller

Økt kvinnesysselsetting har i liten grad minket

tradisjonelle kjønnsforskjeller i yrkesvalg og næringstilknytning.

Tekniske fag er fortsatt sterkt mannsdominert og "omsorgsyrker" er ekstremt kvinnedominert. Hovedtyngden av menn og kvinner jobber fortsatt innen atskilte næringer. I 1990 arbeidet over halvparten av kvinnene i tjenesteyting (både offentlig og privat). Hvis vi i tillegg inkluderer varehandel, hotell og restaurant, sysselsetter disse næringene tre fjerdedeler av alle kvinner. Menn fordeler seg mer jevnt på flere næringer, og det er flere mannsdominerte enn kvinnedominerte næringer.

Økt yrkesaktivitet blant småbarnsmødre....

Arbeidsmønsteret endret seg på 1980-tallet.

Småbarnsmødre brukte mer tid til inntektsgivende arbeid i 1990 enn i 1980. Dette hadde både sammenheng med økt kvinnelig yrkesaktivitet og at flere kvinner arbeidet heltid, også blant småbarnsmødre. Halvparten av de yrkesaktive småbarnsmødrene hadde heltidsjobb i 1991

....flere småbarnsfedre har blitt dobbeltarbeidende Yngre gifte menn uten barn og småbarnsfedre brukte mest tid til inntektsgivende arbeid. Blant småbarnsfedre var det en svak økning i tiden brukt til inntektsgivende arbeid i løpet av 1980 -tallet. Endringer i kvinners og menns yrkes- og familieroller har ført til at det ikke bare er kvinner som er dobbeltarbeidende. Også fedre tar i større grad del i det ulønnede arbeidet, i tillegg til at de ofte har lang arbeidstid i inntektsgivende arbeid. Samlet arbeidstid ble noe lengre for småbarnsfedre enn småbarnsmødre, og både fedre og mødre hadde en travlere hverdag i 1990 enn i 1980.

Menn jobber fortsatt heltid

$\mathrm{Ni}$ av ti yrkesaktive menn var i 1980 - og er fortsatt i begynnelsen av nittiårene - heltidsarbeidende. Ungdom derimot har i økende grad gått over på kort deltid, og kombinerer ofte skolegang med deltidsarbeid.

Kapittel 1 Levekår i Norge. Er graset grønt for alle

1.8.6 Arbeidere og funksjonærer

1.8.7 Arbeidsmiljøet

1.8.8 Lønn

1.8.9 Levekår for langtidsledige

1.8.6. Arbeidere og funksjonærer

Det ble færre arbeidere og flere funksjonærer på middels

og høyere nivå i løpet av 1980-tallet. Økningen i

funksjonærandelen var særlig høy blant kvinner. Fremdeles er det

store forskjeller mellom kvinners og menns sosiale og

$ø$ øonomiske status, men forskjellene er blitt mindre. Det er

fortsatt kvinner som har lavest sosioøkonomisk status.

Andelen sysselsatte som oppgir å ha lederoppgaver, økte

med tre-fire prosentpoeng både for kvinner og menn i løpet av 1980-tallet. Dette gjelder alle stillinger hvor arbeidsledelse inngår som en viktig del av arbeidet, og ikke bare toppstillinger. Det er likevel flest menn som har lederstillinger. 28 prosent av mannlige og 10 prosent av kvinnelige sysselsatte har slike stillinger.

\subsubsection{Lønn}

side 22 av 46 
Lavest vekst i staten og for enkelte arbeidergrupper i privat sektor

Lønnsutviklingen er viktig for levekårene og varierte

endel mellom ulike grupper av satte. Den laveste lønnsveksten på

1980-tallet hadde enkelte arbeidergrupper i privat sektor og

statsansatte.

Reduserte lønnsforskjeller mellom kvinner og menn

Kvinners og menns gjennomsnittlige timelønn økte

omtrent like mye fra 1980 til 1991. Kvinners timelønn i prosent

av menns timelønn økte fra 77 prosent i 1980 til 81 prosent i

1991, altså en svak utjevning. Det var en tilnærming mellom kvinne- og mannslønn i de fleste næringer og bransjer. Avhengig av bransje er imidlertid lønnsforskjellene bare mellom 2 og 6 prosent når man sammenligner kvinner og menn som arbeider $\mathrm{i}$ samme stilling og bedrift. Det er fordelingen av kvinner og menn mellom ulike stillingskategorier som virkelig betyr noe for lønnsforskjellene, mens fordelingen mellom bedrifter og bransjer betyr mindre.

\subsubsection{Arbeidsmiljøet}

Fortsatt belastende arbeid for mange

Arbeidsmiljøet er et viktig levekårsområde. Det viser seg at fysisk belastende og ensidig arbeid er svært vanlig, og at det har vært små endringer i det fysiske arbeidsmiljøet.

Bare på ett område er det klare endringer. Fra 1980 til 1991 økte andelen som oppgir at de arbeider i belastende arbeidsstillinger fra 38 til 44 prosent. Andelen økte bare blant kvinner, fra 33 til 45 prosent. Belastende arbeidsstillinger er nå like vanlige for begge kjønn.

Flere har kontroll over egen arbeidssituasjon. Det har blitt færre som sier at de i liten grad kan bestemme rekkefølgen av, eller planlegge, sine arbeidsoppgaver. Det er særlig arbeidere som har fått bedret sitt arbeidsmiljø på denne måten. Det er også blitt færre som har ensformig arbeid.

Større variasjon i arbeidstidsmønsteret

Det er blitt større variasjon i arbeidstidsmønstre.

Tendensen mot forskjøvede arbeidstider har vært særlig sterk blant unge. Det er nå under 60 prosent av de unge sysselsatte som arbeider ordinær dagtid i sitt hovedyrke. I tillegg er biyrke særlig vanlig blant unge.

\subsubsection{Levekår for langtidsledige}

Den kraftige økningen i arbeidsledigheten har gjort at utvalget ønsket å studere nærmere levekårene til de som har måttet tåle den største belastningen av arbeidsledigheten, nemlig de langtidsledige. I 1992 hadde omlag hver tredje arbeidsløs vært uten arbeid i over et halvt år, mot hver femte i 1988.

Mange har presset økonomi, selv om de fleste klarer å tilpasse seg uten drastiske tiltak

De langtidsledige har en langt mer presset økonomi enn det yrkesaktive har. For eksempel kan nesten halvparten av de førstnevnte ha problemer med å klare løpende utgifter, mot snaut 15 prosent av de sistnevnte. Flertallet av de arbeidsledige tilpasser seg situasjonen uten å måtte ty til drastiske virkemidler, men fem prosent av dem har vært tvunget til å selge huset og 11 prosent har måttet selge bilen. De fleste tilpasser seg imidlertid ved å redusere det løpende forbruket.

Ikke sosialt isolerte, men mer utsatt for psykiske plager Ingen ting tyder på at de langtidsledige er mer sosialt isolerte enn yrkesaktive. Det ser heller ikke ut til at de langtidsledige har trukket seg tilbake fra fysisk eller sosial 
aktivitet.

Selv om få arbeidsledige sier de har psykiske plager

virker de likevel klart mer utsatt enn yrkesbefolkningen forøviig.

Dette gjelder særlig plager som nervøsitet/angst og følelse av

depresjon.

Få av de langtidsledige har vært ledig svært lenge.

Langtidsvirkningene kan derfor bli mer alvorlig enn denne

analysen viser.

Kapittel 1 Levekår i Norge. Er graset grønt for alle

1.9 Trygd og sosialhjelp

1.9.1 Folketrygdens langtidsytelser

1.9.2 Sosialhjelp

\subsection{TRYGD OG SOSIALHJELP}

Med økende problemer på arbeidsmarkedet er alternative former for inntektssikring blitt viktigere i løpet av 1980-tallet. Dette gjelder såvel korttidssytelser som dagpenger under arbeidsledighet, langtidsytelser som uførepensjon, og det sikkerhetsnettet som økonomisk sosialhjelp representerer. Det er også blitt flere alderspensjonister i perioden, og utviklingen i pensjonsytelser har stor betydning for levekårene i denne gruppen. Utvalget har derfor sett på utviklingen i trygdeytelser til ulike grupper trygdemottakere, samt på utviklingen i bruk av økonomisk sosialhjelp.

Mange mottar korttidsytelser, men ingen vesentlig endring på 1980-tallet

Når det gjelder trygder, har utvalget stort sett konsentrert seg om folketrygdens langtidsytelser. Det er likevel slik at både i 1980 og i 1990 mottok rundt en tredjedel av alle trygdemottakere en korttidsytelse. Som en følge av den økte arbeidsledigheten mot slutten av tiåret, var det særlig andelen som fikk dagpenger som økte.

\subsubsection{Folketrygdens langtidsytelser}

Stadig flere får langtidsytelser, i 1991 hele 930000 personer Folketrygdens langtidsytelser omfatter imidlertid en stadig større del av befolkningen. Gjennom hele 1980-årene var det en sterk økning i tallet på personer som fikk langtidsytelser (alderspensjon, uførepensjon, etterlattepensjon og overgangsstønad) fra folketrygden. Mens det i 1980 var 18 prosent av befolkningen som mottok slike utbetalinger, var det i 1991 nesten 22 prosent. I 1991 mottok over 930000 personer en langtidsytelse. Veksten har vært særlig stor i antall uførepensjonister og enslige forsørgere. Kvinner er i flertall, og kvinneandelen har økt svakt gjennom 1980-årene.

Færre minstepensjonister og kvinnene er fortsatt i stort flertall Av samme grunn sank andelen pensjonister som bare hadde minstepensjon. Mens rundt tre av fire alderspensjonister var minstepensjonister i 1980, var bare annenhver minstepensjonist i 1991. Også blant uføre-og etterlattepensjonister ble andelen med bare minstepensjon redusert. For uførepensjonister var reduksjonen fra rundt halvparten til rundt en fjerdedel, og for etterlattepensjonister fra en tredjedel til en sjettedel. Overgangsstønad til enslige 
forsørgere tilsvarer alltid minstepensjon.

I 1991 var 84 prosent av minstepensjonistene kvinner

(alle ordninger under ett).

Reell vekst i minstepensjonene, mens verdien av pensjonen for mange tilleggspensjonister er redusert

Ytelsene fra folketrygden til den enkelte pensjonist vil avhenge av den reelle grunnbeløpsreguleringen, endringer i særtillegget, og endringer i beskatningen. Gjennom 1980-årene bidro disse forholdene til en viss utjevning mellom pensjonister med høye og lave pensjoner.

Særtilleggssatsen økte (for eksempel for enslige pensjonister fra 44,0 prosent i 1980 til 60,5 prosent i 1991) og bidro til en reell vekst for minstepensjonister på rundt 7 prosent $\mathrm{i}$ løpet av perioden. Grunnbeløpsreguleringene, derimot, har ikke fullt ut kompensert for prisstigningen. Realverdien av grunnbeløpet lå i 1992 ca. 1,5 prosent lavere enn i 1980. Pensjonister med mer enn minstepensjon fikk derved redusert verdien av pensjonen sin i takt med grunnbeløpet.

Trygdemottakere skattlegges etter lavere satser enn andre inntektstakere. Inntekter noe over minstepensjonen er sikret skattefrihet gjennom egen skattebegrensningsregel for pensjonister. En del pensjonister med små pensjoner kom etter hvert inn under ordningen i løpet av 1980-årene og de har fått lettere beskatninger. For pensjonister med tilleggspensjoner av noen størrelse, har det derimot vært en viss økning av skattenivået.

Sterk vekst i tallet på alders- og uførepensjonister.... Tallet på alderspensjonister økte med 18,5 prosent fra 1980 til 1991, og i 1991 var det nesten 620000 personer som mottok alderspensjon.

Tallet på uførepensjonister gikk også kraftig opp fra 1980 til 1991. Mens 6,1 prosent av befolkningen i alderen 16-66 år fikk uførepensjon i 1980, var andelen i 19918,5 prosent. I 1991 var det snaut 240000 uførepensjonister, mot snaut $160000 \mathrm{i}$ 1980. I hele perioden var det en viss overvekt av kvinner. Tilgangen på nye uførepensjonister avtok noe mot slutten av 1980 -tallet og gikk ifjor for første gang litt ned. Samtidig var det en vekst i antall personer på attføring.

Tallet på etterlattepensjonister er redusert med nesten en femtedel i perioden, fra vel 42000 i 1980 til snaut 36000 i 1991.

....og i tallet på enslige forsørgere med overgangsstønad I perioden 1983 til 1991 økte antallet enslige forsørgere med overgangsstønad fra vel 26000 til nesten 42000 . Vel 40 prosent av alle enslige forsørgere (her definert som personer med utvidet barnetrygd) mottok overgangsstonad i 1991, og denne andelen har vært stigende gjennom perioden. Tallet på enslige forsørgere i alt i følge denne definisjonen økte fra vel 65000 til vel 98000 i løpet av 1980-tallet.

\subsubsection{Sosialhjelp}

Sosialhjelp: Sterk vekst i utgiftene og en nesten tredobling $i$ antall mottakere

Det var ikke bare trygdeytelsene og antall trygdemottakere som steg. Både utgiftene til økonomisk sosialhjelp og antall sosialhjelpsmottakere økte kraftig på 1980tallet. I faste priser ble det utbetalt 7,3 ganger mer sosialhjelp i 1991 enn i 1980. Kommunenes utgifter til sosialhjelp utgjorde i 19913478 millioner kroner. Antall sosialhjelpsmottakere ble nesten tredoblet fra 1980 til 1990. I 1980 var det vel 60000 stønadstilfeller og dette tilsvarte 15 pr. 1000 personer i 
befolkningen. I 1991 var det vel 172000 stønadstilfeller eller 40 pr. 1000 innbyggere.

I løpet av de tre årene fra 1986 til 1989 økte tallet på sosialhjelpsmottakere med 50 000, en økning på 45 prosent. Veksten har nå stagnert og antall sosialhjelpsmottakere steg bare med 6,6 prosent fra 1989 til 1991.

Ungdom har blitt større forbrukere av sosialhjelp.... I overkant av 10 prosent av aldersgruppa 16-24 år mottok sosialhjelp i kortere eller lengre periode i 1991. Dette var tre ganger flere enn i 1980.

Sosialhjelp er i stor grad et storbyfenomen. Storbyene har et klart høyere nivå enn resten av landet. Oslo har hatt det høyeste nivået og hadde i 1991 hele 67 stønadstilfeller pr. 1000 innbyggere, mot 26 i 1980.

Menn mottar oftere sosialhjelp enn kvinner. Det ble på hele 1980-tallet registrert flere mannlige enn kvinnelige mottakere av sosialhjelp. Særlig enslige menn er mottakere, de har vært den største gruppen på hele 1980-tallet. Mer enn hver tredje sosialhjelpsmottaker i 1990 var enslig mann. Utenlandske statsborgere mottar oftere økonomisk sosialhjelp enn nordmenn. I 1990 var 14 prosent av alle sosialhjelpsmottakere utenlandske statsborgere, og 18 prosent av alle utenlandske statsborgere 16 år og over mottok økonomisk sosialhjelp dette året.

....mens de eldre klarer seg i økende grad uten sosialhjelp De eldre er blitt mindre avhengig av sosialhjelp og utgjør en stadig mindre andel av sosialhjelpsmottakerne. Dette må sees i sammenheng med utbyggingen av folketrygden.

Færre kombinerer lønnsinntekt og sosialhjelp....

Kombinasjonen arbeid og sosialhjelp er blitt mindre vanlig i løpet av 1980-tallet. I 1980 var 26 prosent av sosialhjelpsmottakerne i arbeid på det tidspunktet de henvendte seg til sosialkontoret. I 1990 var denne andelen sunket til 18 prosent, og nedgangen var størst blant menn.

Flere kombinerer trygd og sosialhjelp Kombinasjonen trygdeinntekter og sosialhjelp er blitt mer vanlig. Fra 1986 til 1990 var det en svak vekst i andelen som kombinerte sosialhjelp og trygdeinntekter, og i 1990 mottok 46 prosent av sosialhjelpsmottakerne ytelser fra folketrygden. I overkant av 40 prosent av enslige forsørgere med overgangsstønad mottok økonomisk sosialhjelp i 1990. Blant uførepensjonistene var det tilsvarende tallet 8 prosent. De enslige forsørgere skiller seg også ut ved at de mottok sosialhjelp i lengre tid enn andre trygdemottakere og ved at utbetalingene pr. mottaker var høyere.

Noen arbeidsledige med dagpenger supplerer med sosialhjelp

Enslige forsørgere med overgangsstønad og uførepensjonister utgjorde en relativ stabil andel av sosialhjelpsmottakere på 1980-tallet. Andelen dagpengemottakere økte derimot, fra 5 prosent i 1986 til 12 prosent i 1990. Det er anslått at mellom 6 og 9 prosent av dagpengemottakerne supplerte med sosialhjelp i 1989. Kraftig økning i stønadsperiode og ytelser for sosialhjelp, men tegn til nedgang i ytelsene mot slutten av 1980-tallet Ikke bare tallet på stønadsmottakere har økt, men også stønadslengden. Den gjennomsnittlige stønadslengden pr. år pr. sosialhjelpsmottaker gikk opp fra 3,5 måneder i 1980 til 5,1 måneder i 1990. Andelen sosialhjelpsmottakere som mottok sosialhjelp i 6 måneder eller mer ble nesten fordoblet, fra 21 prosent i 1980 til 40 prosent i 1990.

Sosialhjelpsmottakerne fikk også større ytelser gjennom mesteparten av 1980-tallet. Den gjennomsnittlige stønadssummen pr. måned pr. tilfelle målt i faste kroner ble 
fordoblet fra 1980 til 1988. Fra 1988 til 1991 ble imidlertid realverdien av de månedlige utbetalingene redusert med $i$ underkant av 9 prosent pr. stønadstilfelle. I 1991 var de gjennomsnittlige månedlige utbetalingene 4267 kroner.

Kapittel 1 Levekår i Norge. er graset grønt for alle

1.10 Omsorg

1.10.1 Formell og uformell omsorg

1.10.2 Barneomsorg

1.10.3 Psykisk utviklingshemmede

1.10.4 Eldreomsorg

\subsection{OMSORG}

Tilgang på pleie og omsorg for grupper som trenger det er en viktig side ved befolkningens levekår. Utvalget har konsentrert seg om den omsorgen som spesielt angår mennesker som etter allment aksepterte normer ikke anses å være selvhjulpne i hverdagen. Slik omsorg innebærer at andre må ha ansvar for at elementære og hverdagslige behov for tilsyn, stell, hjelp med husarbeid og per- sonlig hygiene blir oppfylt på en forsvarlig måte.

\subsubsection{Formell og uformell omsorg}

Det er vanlig å skille mellom formell og uformell omsorg.

Den formelle omsorgen blir gitt av det offentlige hjelpeapparatet, den uformelle omsorgen ytes av familie, venner og naboer. Grensene mellom uformell og formell omsorg er ikke allid like klare. I det formelle omsorgssystemet er det som oftest flere omsorgsutøvere som har ulike og spesialiserte omsorgsoppgaver overfor flere omsorgstrengende, mens det uformelle omsorgssystemet er preget av at en eller få har allsidige omsorgsoppgaver overfor den ene eller de få omsorgstrengende. I løpet av 1980-tallet har kapasiteten for å utføre uformelt omsorgsarbeid innen egen husholdning gått ned. Minskende husholdsstørrelse, og særlig økningen $\mathrm{i}$ andelen npersonhusholdninger bidrar til å redusere den andelen som kan få dekket viktige hverdagslige omsorgsbehov ved uformelt omsorgsarbeid. Økt yrkesaktivitet, særlig blant middelaldrende kvinner minsker også mulighetene for dette.

Uformelt omsorgsarbeid har fortsatt stort omfang

Selv om beregningene er usikre, viser imidlertid undersøkelser at det uformelle omsorgsarbeidet for gamle, syke og funksjonshemmede fortsatt er av betydelig omfang sett i forhold til den offentlige omsorgen. Fordi tallene er så usikre er det også vanskelig å anslå hvorvidt omfanget av uformelt omsorgsarbeid har endret seg i løpet av 1980-tallet. Det er imidlertid slik at både andelen menn, og særlig andelen kvinner, som engasjerte seg i uformell omsorg for personer utenfor husholdningen økte på 1980-tallet. Vi vet imidlertid ikke hva slags omsorgsaktiviteter det er snakk om. Det kan være at en del av økningen skyldes at aktiviteter som tidligere ble regnet som sosialt samvær nå i større grad regnes som uformell omsorg. Tiden den enkelte bruker til uformell omsorg kan også ha endret seg. 


\subsubsection{Barneomsorg}

Omsorgen for barn er først og fremst foreldrenes ansvar.

Men det offentlige har en viss plikt til å legge forholdene til rette slik at familiene er i stand til å skjøtte denne oppgaven, blant annet gjennom offentlige overføringer og tilbud om barnetilsyn. Sterk vekst i omfanget av organisert barnetilsyn utenfor hjemmet Langt flere barn under skolepliktig alder har regelmessig tilsyn utenfor hjemmet nå enn tidligere. I 1980 hadde rundt 3 av 10 barn under sju år en form for organisert tilsyn utenfor hjemmet, i 19916 av 10. Denne økningen skyldes utbyggingen av barnehagetilbudet. Barnehagedekningen (andel av alle barn under sju år med barnehageplass) økte fra 21 prosent i 1980 til 38 prosent i 1991. Tallet på barn med barnehageplass vokste mer enn dekningsgraden, fra 78000 i 1980 til vel 150000 i 1991. Årsaken til dette er de økende fødselstallene på slutten av 1980tallet.

Det har vært størst økning i antallet private barnehager og de utgjorde 44 prosent av alle barnehager i 1991. Siden de offentlige barnehagene er større enn de private var andelen barn som gikk i private barnehager noe lavere, snaut 40 prosent, men andelen er økende.

Heldagsplassene øker mest. Mens 46 prosent av barnehageplassene var heldagsplasser i 1985, var andelen økt til 62 prosent i 1991. Fortsatt er barnehagedekningen lavest for de minste barna.

Flest barnehageplasser til ressurssterke grupper Ressurssterke grupper i samfunnet har oftere enn andre barnehageplass. Dette gjelder både når vi ser på sosioøkonomisk status og mødrenes utdanningsnivå. De sosiale forskjeller i barnehagebruk ser ikke ut til å avta. Til tross for en viss fortrinnsrett til opptak for barn av enslige forsørgere, har ikke enslige forsørgere oftere barnehageplass enn andre foreldre. Vekst i antall barn under barnevernstiltak Ved omsorgssvikt eller fare for omsorgssvikt overfor barn kan barnevernet gripe inn. Til tross for at det er blitt færre barn, har antallet barnevernklienter økt gjennom hele 1980-tallet. I 1981 var 9 av 1000 barn under barnevernstiltak mot 18 av 1000 i 1991, i alt vel 20000 barn. Antallet nye barn under barnevernstiltak har også økt på 1980-tallet. Økningen i det totale antall barn under barnevernstiltak skyldes dels at forebyggende tiltak blir brukt mer enn tidligere og at barna blir værende lenger under forebyggende tiltak.

\subsubsection{Psykisk utviklingshemmede}

Ansvaret for psykisk utviklingshemmede ble overtatt av kommunene fra 1991 og omsorgen gikk over fra å være institusjonspreget til mer åpen omsorg. Det er ennå for tidlig å si hva slags levekårskonsekvenser denne omleggingen vil få, både for de psykisk utviklingshemmede selv og deres pårørende. Det er også for tidlig å si noe om belastningen på det kommunale hjelpeapparatet, men det er opplagt at HVPU-reformen vil være svært ressurskrevende for samfunnet. Etter gjennomføringen av HVPU-reformen har kommunene fått ansvar for alle omsorgstjenestene for utviklingshemmede, eldre og uføre.

\subsubsection{Eldreomsorg}

Økning i hjemmesykepleien

Antall årsverk i hjemmesykepleien ble nesten doblet fra 1980 til 1991, mens antall pasienter økte fra 75000 til 127000. Mange flere får hjemmehjelp, men mindre tid på hver enkelt... Antall årsverk i hjemmehjelpen økte med 19 prosent fra 1980 til 1991, mens antall hjem som fikk hjemmehjelp steg med 
40 prosent. Det er altså flere hjem som får hjelp, men det enkelte hjem får mindre tid. Antall ansatte hjemmehjelpere ble nær halvert fra 1980 til 1991. Hver hjemmehjelper jobbet i snitt nesten dobbelt så mange timer i 1991 som i 1980, og hadde nesten tre ganger så mange hjem de utførte hjemmehjelp i. ....særlig nedgang for aldersgruppen 67-79 år

Om vi ser nærmere på brukerne av hjemmehjelp, viser det seg at personer over 79 år fikk økt tilbud om hjemmehjelp på 1980-tallet. De eldre i aldersgruppen 67-79 år hadde en økning i tilbudet fram til 1987, men en reduksjon fra 1987 til 1991. Totalt sett var det færre av denne gruppen eldre som fikk hjemmehjelp i 1991 enn i 1980, og antall timer pr. hjem ble også kraftig redusert. Det er særlig de aleneboende kvinnene i denne aldersgruppen som har fått tilbudet redusert. Mindre hjelpebehov for den enkelte kan ikke forklare verken nedgangen $i$ hjemmehjelpstilbudet, eller kjønnsforskjellene. Det er særlig i tettbygde strøk at tilbudet av hjemmehjelp for de i aldersgruppen 67-79 år er blitt redusert.

Ved utbyggingen av de hjemmebaserte tjenestene for eldre og uføre har en i særlig grad fokusert på behovene hos de aller eldste, det vil si de som er over 79 år. Denne fokuseringen kan ha bidratt til en forverring av tjenestetilbudet for dem under 80 år. Tendensen gjør seg også gjeldende for hjemmesykepleietilbudet, men ikke i samme grad som i hjemmehjelpstjenesten.

Lavere dekningsgrad av institusjonsplasser i eldreomsorgen Antall institusjonsplasser i eldreomsorgen økte med 13 prosent fra 1980 til 1991. Regnet i forhold til tallet på personer over 66 år gikk imidlertid antallet institusjonsplasser ned.

\author{
Kapittel 1 Levekår i Norge. Er graset grønt for alle \\ 1.11 Boforhold og boligmarked \\ 1.11.1 Boligstandard \\ 1.11.2 Boligmarkedet \\ 1.11.3 Bokostnader \\ 1.11.4 Boligkarriere
}

\title{
1.11. BOFORHOLD OG BOLIGMARKED
}

\subsubsection{Boligstandard}

Klar økning i boligstandarden, også for de svakeste gruppene Nordmenn hadde allerede i 1980 en høy boligstandard.

Den ble enda bedre på 1980-tallet, først og fremst fram til 198788. I 1991 bodde ti prosent av den voksne befolkning i umoderne boliger, som enten manglet bad eller WC eller hadde kalde eller fuktige rom. Dette var nær en halvering siden 1980. Denne forbedringen i boligstandarden var størst i grupper med lavest standard slik at det skjedde en utjevning $i$ befolkningens boligstandard. I 1991 var det eldre enslige, enslige forsørgere og yngre som hadde den dårligste boligstandarden.

Også andelen trangbodde ble halvert det siste tiåret, $\mathrm{i}$ 1991 bodde 8 prosent av alle voksne trangt. Forbedringen har også her vært størst i de gruppene med størst trangboddhet i 1980, men fortsatt bor om lag 20 prosent av småbarnsfamiliene trangt.

De fleste er selveiere og bor i småhus 
Det er lange tradisjoner for og sterke preferanser for å eie bolig i Norge. I 1990 eide om lag 80 prosent av husholdningene sin bolig enten selv eller gjennom borettslag. Denne andelen økte på 1980-tallet. Nordmenn bor også i overveiende grad i småhus, i 1991 gjaldt det 84 prosent av alle voksne. Småhusboende økte også det siste tiåret, fordi flere bodde i frittliggende enebolig.

\subsubsection{Boligmarkedet}

Turbulent boligmarked på 1980-tallet

Boligmarkedet på 1980-tallet var karakterisert av store endringer. Boligmarkedet ble deregulert på begynnelsen av tiåret og det regulerte marked er nå så godt som borte. Byggingen av nye boliger ble kraftig redusert i løpet av tiåret. Dessuten skiftet boligbyggingen karakter. Til forskjell fra situasjonen på begynnelsen av både 1980- og 1990-tallet var det på midten av 1980-tallet et stort innslag av privatfinansierte boliger, og det ble bygget mange store boliger. Dereguleringene av boligmarkedet og av kredittmarkedet førte til sterk prisøkning fram til 1988. Det sterke prisfallet som startet da, har sammen med utviklingen på arbeidsmarkedet ført til en vanskelig økonomisk situasjon for en del husholdninger.

\subsubsection{Bokostnader}

Sterk økning i bokostnadene

Utviklingen i bolig- og kredittmarkedet førte til en sterk $ø$ øning av bokostnadene på 1980-tallet. Nesten hele denne $ø$ øningen kom i perioden mellom 1983 og 1988. Boutgiftene var i 1991 den største hovedpost på husholdningsbudsjettet, og sto for vel en fjerdedel av utgiftene i følge forbruksundersøkelsene. De gjennomsnittlige boutgifter økte fra 27000 til 49000 kroner i perioden 1980-91 (1991-kroner). Det meste av økningen skyldtes renteutgiftene som steg med vel 16000 kroner. Økningen i renteutgifter skyldtes først og fremst en økning i gjelden, både fordi boligeierne økte sin boliggjeld og fordi det ble flere eiere. Sammenliknet med situasjonen på midten av 1980tallet kommer i tillegg at gjeldsrentene ikke gir samme reduksjon i skatten, særlig for høyinntektsgrupper, og at realrentenivået er vesentlig høyere på grunn av lavere prisstigning. Det er imidlertid også grunn til å peke på at høyere boutgifter i noen grad skyldes høyere boligstandard.

Det er enslige i yrkesaktiv alder som bruker relativt sett mest på bolig, om lag en tredjedel av forbruket gikk til bolig rundt 1990. Det er imidlertid småbarnsfamiliene som har de største boutgiftene. I perioden 1989-91 var boutgiftene deres i gjennomsnitt 75000 1991-kroner pr. år. De hadde også den største økningen i boutgifter. Den største relative økningen hadde imidlertid yngre par uten barn.

\subsubsection{Boligkarriere}

Flere kjøpte bolig tidlig i livet....

På 1980-tallet ble husholdningene boligeiere stadig tidligere i livet. Over 80 prosent av husholdningene med hovedperson i første halvdel av 30-årene eide sin egen bolig på begynnelsen av 1990-tallet. Kjøp av bolig er nært knyttet til pardannelse. Når midten av 30-årene er passert er det først og fremst blant ugifte at eierandelen er lav. Også samboere og før gifte har klart lavere eierandel enn gifte, noe som henger sammen med at de oftere er andelseiere.

....og flere skiftet bolig

På 1980-tallet så man også en tendens til at husholdningene skiftet bolig oftere enn før. Tidligere ble husholdningene i stor utstrekning boende i den bolig de hadde anskaffet. Det gjaldt særlig for de som hadde flyttet inn i ny selveierbolig. Om den økte tilbøyelighet til å skifte bolig gjaldt 
for alle livsfaser vet vi ikke. Tidlig på 1990-tallet var imidlertid markedserfaringen blant dem som var i 30-årene allerede større enn blant dem som hadde passert 50 år.

At prisfall på bolig, i kombinasjon med andre

omstendigheter, kan tvinge en boligeier til å selge er noe forholdsvis nytt. En slik overgang fra større til mindre bolig som følge av markedsutviklingen forekommer likevel forholdsvis sjelden og langt sjeldnere enn på grunn av samlivsbrudd.

\section{Kapittel 1 Levekår i Norge. Er graset grønt for alle \\ 1.12 Helse og sosiale forhold \\ 1.12.1 Helsevesenet og helsetilstand \\ 1.12.2 Sosiale relasjoner \\ 1.12.3 Trygghet for liv og eiendom \\ 1.12.4 Fritid}

\subsection{HELSE OG SOSIALE FORHOLD}

Ikke-materielle sider ved levekårene som helsetilstand, familie- og vennskapskontakter, trygghet for liv og eiendom, fritid og kulturell/politisk deltakelse kan være vel så viktige for velferden som inntekt, sysselsetting og bostandard. Helse ses ofte på som en særlig viktig levekårskomponent. Sammenlignet med sysselsettingen og de materielle sidene ved levekårene er det imidlertid vanskeligere å styre fordelingen av dette godet ved hjelp av politiske tiltak.

\subsubsection{Helsevesenet og helsetilstand}

Fortsatt betydelig vekst i helsetjenesten, særlig i helsetjenesten utenfor institusjoner

Samfunnet bruker betydelige ressurser til å ivareta befolkningens helsetilstand. Nesten 200000 personer arbeidet $\mathrm{i}$ helsetjenesten i 1990, samme år kostet helsetjenesten omkring 50 milliarder kroner. 7,5 prosent av bruttonasjonalproduktet ble brukt til helseformål. Ressursbruken vokste på 1980-tallet, spesielt var økningen sterk i helsetjenesten utenfor institusjon, med en realvekst på 53 prosent i perioden 1980-90. Veksten i antall årsverk i helsetjenesten dette tiåret var 22 prosent. Veksten i helsesektoren var imidlertid langt mindre på 1980-tallet enn i det foregående tiåret. Også befolkningens kontakter med helsevesenet økte på 1980-tallet, det ble gjennomført flere behandlinger og konsultasjoner enn tidligere. Utvalget har ikke vurdert om den økte ressursinnsatsen står i forhold til veksten i etterspørselen, blant annet på grunn av det stigende antall eldre. Helsetilstanden: Høyere levealder....

Et viktig spørsmål er om økt ressursbruk har forbedret helsetilstanden. Målt som økning i levealderen har helsetilstanden i befolkningen utvilsomt blitt bedre de siste årene. Den forventede levealderen de siste 10-15 årene har økt med om lag 2 år for menn og 1,5 år for kvinner. Det er spesielt dødeligheten av hjerte/karsykdommer som er redusert de siste årene. Fra 1989 til 1991 var det også en klar nedgang i spedbarnsdødeligheten, som hadde sammenheng med en halvering av antallet krybbedødsfall. ....men liten endring i sykeligheten Omkring en femtedel av den voksne befolkningen sier at de har sykdommer som virker inn på hverdagen "i betydelig grad". Omfanget av sykelighet og nedsatt funksjonsevne i befolkningen har endret seg lite det siste tiåret, i følge helse- og 
levekårsundersøkelser. Delvis skyldes dette flere eldre og den nevnte økning i levealderen. Nye sykdommer har dessuten til en viss grad erstattet de gamle plagene.

Noen helseproblemer er blitt mer utbredt Visse typer sykelighet er økende. Aldersjusterte tall viser en vekst i antallet nye tilfeller av ondartede svulster, likeledes har kreftdødeligheten økt. Veksten har vært sterkest blant menn. Noe av økningen kan skyldes tidligere og bedre diagnostisering. Det har også vært en økning i oppgitte tilfeller av hudsykdommer. Blant kvinner i yrkesaktiv alder er det flere som oppgir at de har en muskel- eller skjelettlidelse, mens det ikke har vært noen $ø$ øning blant menn. Vi vet ikke hva som er årsakene til veksten hos kvinner, men det kan være grunn til å peke på økningen i sysselsetting og arbeidstid blant kvinner i yrkesaktiv alder. Flere sysselsatte kvinner sier arbeidet innebærer belastende arbeidsstillinger. Mer enn fire av ti heltidsansatte kvinner har vondt i skuldre eller armer minst en av dagene i uken, dobbelt så mange som blant menn.

Ingen økning i psykiske lidelser blant folk flest

Det har ikke blitt flere som oppgir at de har psykiske

lidelser, i følge helse- og levekårsundersøkelsene. En må regne med en betydelig underrapportering av slike problemer $\mathrm{i}$ intervjuundersøkelsene, men det er få holdepunkter for å anta at underrapporteringen er blitt større over tid. Det er imidlertid grunn til å anta at de mest alvorlige depresjonene ikke fanges opp i slike undersøkelser.

Økningen i selvmordsratene er et tegn på at flere rammes av alvorlige depresjoner. 675 personer tok sitt eget liv i 1991 mot 507 registrerte selvmord i 1980.

Flere uførepensjonerte og langtidssykemeldte Antallet uførepensjonerte og langtidssykemeldte har økt sterkt på 1980-tallet. Denne utviklingen kan imidlertid i liten grad ses som uttrykk for en forverring av helsetilstanden. En av flere delforklaringer er sannsynligvis utviklingen på arbeidsmarkedet, med stigende arbeidsledighet. Det er videre mulig at økningen i muskel- og skjelettlidelsene blant kvinner har bidratt til at flere kvinner er uførepensjonerte og langtidssykemeldte. Muskel- og skjelettlidelsene er de viktigste direkte medisinske årsakene til langtidsfravær og uførepensjonering.

\subsubsection{Sosiale relasjoner}

Flere skilsmisser og aleneboende, men mer kontakt med venner Utvalget peker på tre hovedtrekk i utviklingen av familieog vennskapsforhold i samfunnet: For det første har det skjedd store endringer i familiemønstrene på relativt kort tid. Ekteskapet som samfunnsinstitusjon ser ut til å være under press, med flere samboere og et økende antall skilsmisser. I forhold til antall ektepar, er tallet på skilsmisser fordoblet de siste 20 årene. Antallet barn under 18 år som hvert år berøres av skilsmisser økte fra om lag 8000 i 1982 til om lag 10000 i 1990. For det andre er det blitt flere enslige, og langt flere som bor alene, spesielt i de yngre aldersgruppene. 17 prosent av den voksne befolkningen bodde alene i 1991 mot 12 prosent i 1980. For det tredje har samværet med venner økt på 1980-tallet. Andelen som oppgir at de mangler en "fortrolig venn" utenom egen familie er redusert fra 27 prosent i 1980 til 18 prosent i 1991. Foreldre hadde noe hyppigere kontakt med barn som var flyttet hjemmefra i 1991 enn i 1980.

Disse tre utviklingstrekkene synes å innebære en viss forskyvning av kontaktmønsteret i befolkningen, vennskap utenfor eget hushold har økt i betydning.

Tidsnyttingsundersøkelsene viser at vi tilbringer en mindre del av tiden i boligen enn for ti år siden, både på hverdager og i helgene. Også tiden som tilbringes i nærmiljøet er redusert. 
Neppe mindre ensomhet og om lag 5 prosent mangler en fortrolige venn

Vi vet ikke om denne utviklingen også har ført til at det er blitt færre ensomme i befolkningen. Enkelte undersøkelser tyder på at ensomhetsfølelsen i samfunnet ikke er redusert i samme omfang som den sosiale kontakthyppigheten har økt. Dette kan ha flere årsaker, det er blant annet grunn til å tro at det økende antallet samlivsoppløsninger betyr mer for ensomheten enn den økte kontakthyppigheten utenfor husholdet. Det er svært få i den voksne befolkningen som ikke har noen form for jevnlig sosial kontakt. Noen mangler det en kan kalle fortrolige relasjoner. I 1991 var det fem prosent i den voksne befolkningen, omkring 150000 mennesker, som hverken var gift/samboende eller hadde en "fortrolig venn" utenom sin egen familie.

\subsubsection{Trygghet for liv og eiendom}

Flere drap og grove voldsforbrytelser, større utrygghet blant kvinner

Trygghet for liv og eiendom er en viktig side ved velferden. Det er mye som tyder på at denne tryggheten er svekket i de senere årene. Antallet forbrytelser som ble etterforsket av politiet økte meget sterkt på 1980-tallet, og antallet grove voldsforbrytelser steg mer enn annen kriminalitet. Det ble begått flere drap på slutten av tiåret enn i begynnelsen av tiåret. For begge kjønn har det vært en fordobling av antall drapsofre i løpet av de siste 20 årene.

Mer grov vold har gjort at flere kvinner føler seg utrygge, særlig yngre kvinner i storbyene.

....men antall voldsofre har $ø \mathrm{kt}$ lite

Det er likevel grunn til å tro at den faktiske voldskriminaliteten har steget mindre enn den registrerte. Anmeldelseshyppigheten har sannnsynligvis økt for en del forbrytelser, blant annet for grove sedelighetsforbrytelser. I følge levekårsundersøkelsene var andelen som hadde fått synlige merker eller kroppsskade av voldshandling i løpet av de siste 12 måneder den samme i 1991 som i 1983 (1,3 prosent). I samme periode var det en viss økning i andelen som hadde vært utsatt for vold eller trusler i alt (fra 3,9 til 5,1 prosent).

\subsubsection{Fritid}

Liten økning i fritiden, mindre fritid for småbarnsforeldre

Det er et velferdsgode å ha tilstrekkelig fritid, tid til å kople av og dyrke egne interesser. Fritiden for hele befolkningen sett under ett økte noe på 1980-tallet, men økningen var liten, bare 9 minutter i gjennomsnitt pr. dag. På 1970-tallet økte fritiden i gjennomsnitt med nesten en time.

Økningen i fritiden fra 1980 til 1990 var mest markert blant dem som hadde mye fritid i 1980. Småbarnsforeldre har fått mindre fritid det siste tiåret, mens enslige menn har fått mer fritid.

Aktiv og utadvendt fritid, mindre politisk deltakelse En stigende andel av befolkningen oppsøker restauranter, kafeer og dansetilstelninger. Av kulturaktivitetene er det museums- og konsertbesøkene som har økt mest. En større andel av befolkningen mosjonerer omtrent ukentlig. Om lag halvparten av den voksne befolkningen er aktive i ulike organisasjoner. Organisasjonsdeltakelsen endret seg lite på 1980-tallet, blant kvinner var det en svak økning i deltakelsen. Et av de få unntakene fra tendensen til økende aktivitet, er deltakelsen i politiske partier. 17 prosent i den voksne befolkningen var medlem av et politisk parti i 1980, og bare 12 prosent i 1991. Andelen som var aktiv i et politisk parti ble redusert fra 6 til 4 
prosent.

\author{
Kapittel 1 Levekår i Norge. Er graset grønt for alle \\ 1.13 levekår for grupper \\ 1.13.1 Barnefamiliene \\ 1.13.2 Enslige forsørgere \\ 1.13.3 Barn \\ 1.13.4 Ungdom
}

\title{
1.13. LEVEKÅR FOR GRUPPER
}

I beskrivelsen av ulike gruppers levekår, har utvalget tatt utgangspunkt i grupper som har en viss stabilitet, er av en viss størrelse og har vært mye framme i den offentlige debatten. Det betyr ikke at alle de grupper som er beskrevet nødvendigvis har dårlige levekår eller en særlig dårlig levekårsutvikling på 1980tallet.

\subsubsection{Barnefamiliene}

Selv om foreldrene i gjennomsnitt er blitt eldre, er barnefamilienes etableringskostnader tyngende, med et betydelig behov for inntekter og dermed også arbeidsinnsats.

Omsorgsansvaret for barn tar også tid, og mange barnefamilier har kommet i en tidsmessig presset situasjon.

Småbarnsfamiliene bruker mer tid på inntektsgivende arbeid.... Samlet arbeidstid pr. uke for småbarnsforeldre økte med nesten 5 timer på 1980-tallet. Årsaken til dette er først og fremst den økte yrkesaktiviteten blant småbarnsmødre, men også at flere småbarnsfedre har lengre ukentlig arbeidstid. I gjennomsnitt over året brukte småbarnsfamilier samlet 53 timer pr. uke til inntektsgivende arbeid i 1990 ifølge tidsnyttingsundersøkelsen. Foreldre med skolebarn brukte 66 timer.

....men like mye som før til direkte omsorg for barn

At far og mor har mer yrkesarbeid fører ikke til at tiden brukt til direkte omsorg for barn blir redusert. Det har imidlertid skjedd en omprioritering fra vanlig husarbeid til omsorg for barn. Denne omprioriteringen gjelder både fedre og mødre.

Småbarnsforeldre hadde mindre egen fritid i 1990 enn de hadde $i$ 1980 , mens det ikke har vært noen endring i familier med skolebarn.

Gunstig inntektsutvikling for de aller fleste barnefamiliene, men de svakest stilte har klart sakket akterut

Barnefamiliene, og særlig småbarnsfamiliene, har hatt en bedre inntektsutvikling enn husholdningene under ett.

Småbarnsfamiliene har likevel fremdeles en lavere husholdningsinntekt enn gjennomsnittet for alle husholdninger. Inntektsforskjellene innenfor de to familietypene har imidlertid blitt større. Både blant småbarnsfamiliene og skolebarnsfamiliene har den fjerdedelen med lavest inntekt klart sakket akterut. Dette gjelder ikke bare inntekt, men også når en ser på bostandard og eierforhold til bolig.

De barnefamiliene som tilhører den fjerdedelen med lavest inntekt har også oftere enn resten økonomiske problemer. Blant skolebarnsfamiliene er det stort sett bare denne gruppen som har $ø$ konomiske problemer. Blant småbarnsfamiliene derimot, er det også flere som tilhører høyere inntektsgrupper som oppgir at de har økonomiske problemer. 


\subsubsection{Enslige forsørgere}

Sterk vekst i antallet på 1980-tallet

Tallet på enslige forsørgere økte sterkt på 1980-tallet, og ved utgangen av 1991 var det snaut 110000 enslige forsørgere i Norge. Enslige forsørgere er som oftest i alderen 25-44 år, de fleste er kvinner og de har oftere ett enn flere barn. Enslige forsørgere har dårligere levekår enn andre, men store forskjeller innen gruppen

Enslige forsørgere har generelt dårligere levekår enn andre befolkningsgrupper, for eksempel gifte/samboende med barn. Men levekårsforskjellene er store innen gruppen av enslige forsørgere. En stor gruppe enslige forsørgere har lav yrkesdeltakelse, sliter med dårlig økonomi og lav materiell standard, samtidig som andre enslige forsørgere har solid utdanning, høy yrkesdeltakelse, god økonomi og relativt høy materiell standard.

De fleste enslige forsørgere mottar overgangsstønad med en gjennomsnittlig stønadslengde på 3 år. Enslige forsørgere med overgangsstønad har jevnt over de dårligste levekårene, mens enslige forsørgere med bare stønad til barnetilsyn har gjennomgående like gode og i noen tilfeller bedre levekår enn gifte/samboende med barn. Enslige forsørgere uten stønad er i en mellomstilling.

Få enslige forsørgere med overgangsstønad har høy utdanning, og de har oftere enn andre enslige forsørgere $ø$ øonomiske problemer. De er også oftere avhengig av $ø$ øonomisk sosialhjelp. Bil og fritidsbolig er mindre vanlig, og de eier sjeldnere enn andre sin bolig.

\subsubsection{Barn}

Flere opplever at foreldrene flytter fra hverandre

Det er opplagt at de levekårsforskjeller og utviklingstrekk vi finner i ulike barnefamilier vil ha stor betydning også for barnas levekår. Viktige utviklingstrekk på 1980-tallet sett fra barnas synsvinkel, er antakelig den økte tiden både far og mor bruker på arbeid utenfor hjemmet (se over), samt endringer i familiemønstret. En økende andel barn blir født av samboende ikke gifte - foreldre, og en økende andel av barna opplever at foreldrene flytter fra hverandre. Disse to tendenser henger sammen; barn av samboende foreldre har to til tre ganger så stor sannsynlighet for å oppleve samlivsbrudd som barn av gifte foreldre. Ni av ti barn blir boende hos mor etter et samlivsbrudd. Barn bor ofte i husholdninger med lav inntekt pr. forbruksenhet Selv om barnefamiliene hadde en gunstig inntektsutvikling på 1980-tallet, er det likevel slik at barn ofte bor i husholdninger med lav inntekt pr. forbruksenhet. 8 prosent av barna (0-15 år) bodde i en husholdning som mottok sosialhjelp i 1991. Hvert fjerde barn av enslige forsørgere bodde i en slik husholdning.

De fleste barn har stort sett god helse

Barn og unge har stort sett god helse. Men andelen barn som rammes av hudsykdommer ble fordoblet fra 1975 til 1985, og dette var den vanligste sykdommen blant barn. I 1985 var sykdommer i åndedrettsorganer den nest vanligste sykdommen blant barn. En av grunnene til denne utviklingen kan være en forverring av barns inne- og utemiljø.

Antall dødsfall blant barn har gått ned siden 1985, og det er spesielt dødsfall på grunn av sykdom som har vist en markert nedgang. Ulykker er den viktigste dødsårsaken blant barn. Ulykkesdødeligheten blant barn er også blitt sterkt redusert de siste 15 årene. Over 125000 barn søker årlig legehjelp for en skade i forbindelse med ulykker. Gutter er oftere utsatt for ulykker enn jenter, og de yngste barna er mest utsatt. 


\subsubsection{Ungdom}

Overgangen til voksenrollen gjør at ungdommens livssituasjon er preget av endring på mange områder. I løpet av en kort periode skal de flytte hjemmefra, avslutte utdanning og gå ut i yrkeslivet, stifte familie og få barn.

Dagens ungdom har tidligere samlivsstart, men senere barnefødsler sammenlignet med tidligere ungdomsgenerasjoner. Halvparten av guttene bodde hjemme til de var i midten av 20årene i 1991, mot bare en av fem jenter i samme alder.

Sterk nedgang i sysselsettingen, og høyere ledighet.... Det har vært sterk nedgang i sysselsettingen blant ungdom, langt sterkere enn i befolkningen forøvrig, og ungdommen har høyest ledighet. Langtidsledigheten er økende også blant ungdom. De ungdommene som er yrkesaktive er ofte i underordnede posisjoner $\mathrm{i}$ arbeidslivet, og $\mathrm{i}$ jobber med dårlig arbeidsmiljø. Lavtlønnsandelen er dessuten økende.

....men klar vekst i utdanningsaktiviteten

Den dårlige situasjonen på arbeidsmarkedet har ført til en større utdanningsaktivitet blant ungdom og utdanningslengden har økt. Andelen som gikk fra videregående skole til arbeidsmarkedet ble sterkt redusert på 1980-tallet. Men kapasitetsbegrensninger blant annet på yrkesfaglige linjer førte til at elevene ofte måtte pendle på kryss og tvers mellom ulike kurs og nivåer. Mange studenter og skoleelever har deltidsarbeid ved siden av studier og skolegang. Blant de yngste ungdommene ble denne andelen redusert mot slutten av 1980-tallet, men ikke for de litt eldre. Deltidsarbeidsmarkedet for ungdommen ser altså ikke ut til å være fullt så preget av nedgangskonjunkturen som arbeidsmarkedet forøvrig.

Ungdom har hatt en dårlig inntekts- og forbruks-utvikling og bruker mer sosialhjelp enn før Ungdom tilhører ikke bare i økende grad lavtlønnsgruppen. De har også hatt en negativ inntekts- og forbruksutvikling. Fra 1982 til 1990 var ungdommen den eneste aldersgruppen hvor andelen med lav husholdningsinntekt økte. Ungdom er også en av de få grupper som måtte stramme inn sitt forbruk i siste del av 1980-tallet. En av fem som har flyttet hjemmefra, har ofte eller av og til økonomiske problemer. Økonomisk sosialhjelp er blitt en stadig hyppigere løsning for ungdom gjennom 1980-tallet.

Ungdom har en noe dårligere bostandard enn eldre aldersgrupper, og mange unge som har flyttet hjemmefra bor trangt. Dette er antakelig ingen indikasjon på at mange av dagens unge også vil ha dårligere boforhold gjennom resten av livet, men heller på at mange bor litt enkelt i en etableringsfase.

Ungdom har et aktivt fritidsmønster....

Ungdom har mer fritid enn resten av befolkningen, men de fikk ikke mer fritid på 1980-tallet. Guttene har litt mer fritid enn jentene. Ungdom har et aktivt fritidsmønster sammenlignet med andre aldersgrupper. De er både mer fysisk aktive og deltar mer i underholdningsaktiviteter og kulturelle begivenheter. I løpet av 1980-tallet ble særlig jentene mer fysisk aktive. Karakteristiske trekk ellers er at fritiden i stor grad tilbringes utenfor hjemmet, og i økende grad også utenfor nærmiljøet. En betydelig del av tiden tilbringes sammen med venner, og fjernsynet opptar en mindre del av fritiden blant ungdom enn $i$ andre aldersgrupper. 
Selv om ungdom har god fysisk og psykisk helse sammenlignet med eldre, opptrer imidlertid noen psykiske og sosiale problemer hyppigere blant ungdom, og særlig blant unge menn.

Unge gutter er tre ganger så ofte utsatt for vold som resten av befolkningen, og en økende andel av jentene er utsatt for trusler om vold. Unge menn er ikke bare utsatt for kriminelle handlinger, de begår også oftere kriminelle handlinger.

Selvmordsraten blant unge menn øker. Selvmordsforsøk forekommer hyppigst blant kvinner og menn mellom 20 og 30 år. Ulykkesdødeligheten er derimot synkende. Likevel er ulykker en hyppig dødsårsak blant ungdom. Selv om ungdom - og særlig unge menn - har et høyt alkoholkonsum, endret ikke dette seg på 1980-tallet.

Kapittel 1 Levekår i Norge. Er graset grønt for alle

1.13.5 Eldre

1.13.6 Funksjoneshemmede

1.13.7 Innvandrere

\subsubsection{Eldre}

Gunstig inntektsutvikling på 1980-tallet...

Eldres inntekter er under gjennomsnittet. Dette gjelder særlig enslige eldre. Inntektsutviklingen har imidlertid vært gunstig. Målt i disponibel inntekt var realveksten for eldrehusholdingene om lag dobbelt så stor som for husholdninger i alt fra 1982 til 1990. Dette skyldtes først og fremst en økning i antall pensjonister med tilleggspensjon og dermed færre minstepensjonister. Det var dessuten en økning i de eldres kapitalinntekter. Også når vi ser på forbruksutgifter, er bildet at de eldre har bedret sine økonomiske levekår i løpet av 1980tallet. Inntektene er ikke mer skjevt fordelt mellom ulike grupper av eldrehushold i 1990 enn i 1982.

....men fortsatt stram økonomi for eldre minstepensjonister Selv om eldre generelt sett sjelden oppgir å ha økonomiske problemer, er det verdt å merke seg at enslige eldre, og de eldste eldre, oftere enn andre eldre har en stram økonomi. En stor del av disse er eldre kvinner med minstepensjon.

Klar bedring i boligstandard

Bostandarden til de eldre økte betraktelig på 1980-tallet, selv i forhold til den generelt gunstige utvikling i bostandarden. Men også på dette området sakker de eldste kvinnene relativt sett akterut. De bodde oftere enn andre i boliger som var kalde og vanskelige å varme opp og i boliger uten bad eller wc i 1991. Mange eldre er plaget av sykdom....

Eldre kvinner har høy sykelighet, og høyere enn menn på samme alder. 8 av 10 gamle kvinner har en eller flere langvarige sykdommer og mer enn 4 av 10 har sykdommer med betydelige konsekvenser for hverdagen. Eldre kvinner har også ofte psykiske lidelser.

....men bedret helsetilstand i løpet av 1980-tallet

Helsetilstanden, målt som funksjonsevne, bedret seg noe på 1980-tallet. Det var særlig eldre menns helsetilstand som utviklet seg gunstig.

Til tross for større sykelighet, kan eldre kvinner regne med å leve lenger enn eldre menn. I 1991 kunne en 70 år gammel kvinne regne med å leve i snaut 15 år til; en 70 år gammel mann 
kunne regne med å leve om lag 11,5 år til. Forskjellen ble større i løpet av 1980-tallet, selv om både kvinner og menn har hatt en gunstig utvikling.

Mange eldre bor alene

Mange eldre, og særlig eldre kvinner bor alene. Mer enn

halvparten av de eldre kvinnene bor alene. Det at eldre bor alene

betyr ikke at de er isolerte. De fleste eldre har like god eller til dels bedre familiekontakt enn det som er vanlig i befolkningen, og det har vært liten endring i dette på 1980-tallet. De eldre har imidlertid mindre kontakt med venner enn andre befolkningsgrupper. Utviklingen i omfanget av kontakten med venner har imidlertid vært positiv, særlig blant eldre kvinner. Blant de eldste eldre kan det imidlertid se ut som om liten sosial kontakt er vanligere enn blant folk flest.

De eldre har fått mer fritid, og de har også fått en mer aktiv fritid. Mange eldre kvinner er imidlertid redde for å bli utsatt for vold og trusler når de går ute alene der de bor.

\subsubsection{Funksjonshemmede}

Med gruppen funksjonshemmede mener vi personer i alderen 16-66 år som mottar uførepensjon og/eller grunn- eller hjelpestønad, eller som ikke klarer grunnleggende daglige gjøremål som innkjøp eller vask og rengjøring av bolig. To tredjedeler av de funksjonshemmede er i alderen 45-66 år, dobbelt så stor andel som i befolkningen 16-66 år.

Lav sysselsetting blant de funksjonshemmede

Levekårsundersøkelsen i 1991 viser at 38 prosent av funksjonshemmede menn og 32 prosent av funksjonshemmede kvinner var sysselsatt. Sammenliknet med aldersgruppen 45-66 år var dette halvparten av sysselsettingsandelen for kvinner og litt under halvparten for menn.

Sysselsatte funksjonshemmede menn arbeidet oftere deltid enn andre menn, sysselsatte funksjonshemmede kvinner arbeidet oftere kort deltid enn andre kvinner. Over halvparten av de sysselsatte funksjonshemmede arbeidet deltid, om lag 40 prosent blant menn og to tredjedeler blant kvinner.

De funksjonshemmede er oftere lavtlønt....

Blant funksjonshemmede lønnstakerne var 26 prosent menn og 52 prosent kvinner lavtlønt. Tilsvarende tall for alle lønnstakere i aldersgruppen 45-66 år var 9 prosent for menn og 35 prosent for kvinner. Blant lønnstakere i aldersgruppen 16-66 år var andelen lavlønt 32 prosent.

Sammenliknet med 45-66-åringer hadde funksjonshemmede kvinner om lag samme utdanningsnivå.

Funksjonshemmede menn hadde noe lavere utdanningsnivå. 47 prosent hadde utdanning utover grunnskolen, 9 prosent utdanning på universitets- og høgskolenivå, sammenliknet med henholdsvis 57 og 22 prosent blant gjennomsnittet av 45-66årige menn.

....og har oftere økonomiske problemer Den materielle standard og boligstandarden synes å være noe dårligere, forskjellene er imidlertid forholdsvis beskjedne. Et vesentlig større omfang av økonomiske problemer blant de funksjonshemmede enn for befolkningen i yrkesaktiv alder kan tyde på et svakt inntektsgrunnlag for en del i denne gruppen. Aktiv fritid Funksjonshemmede har ikke en spesielt passiv fritid. Andelen som har deltatt i kulturelle aktiviteter og underholdningsaktiviteter er bare litt mindre enn i befolkningen i alderen 16-66 år. En vet at unge er meget aktive i fritiden. Tar en 
hensyn til at det store flertall er i alderen 45-66 år og sammenlikner de funksjonshemmede med denne aldersgruppen blir forskjellene små.

Andelen som driver med sport eller mosjonerer er ikke vesentlig lavere blant de funksjonshemmede enn blant middelaldrende generelt, om enn noe lavere enn generelt for personer i yrkesaktiv alder.

Det er for de fleste mål på sosial kontakt litt flere av de funksjonshemmede som mangler kontakt enn i sammenliknbare grupper, men forskjellene er ikke store.

\subsubsection{Innvandrere}

Antallet utenlandske statsborgere er fordoblet siden 1978. I 1992 var 148000 personer eller 3,5 prosent av den norske befolkningen utenlandske statsborgere. Nøyaktig 50 prosent av disse kommer fra et annet europeisk land. Om lag 7 prosent kommer fra USA, Canada eller Australia. Det er 30 prosent av innvandrerne som kommer fra Asia, 7 prosent fra Afrika og 5 prosent fra Latin-Amerika.

Tallet på innvandrere var 330000 dersom vi lar gruppen omfatte alle som er født i utlandet, og de som er født i Norge av foreldre hvor minst en er født i utlandet. Dette var i 1992 7,8 prosent av befolkningen i Norge.

En betydelig del av innvandringen til Norge er nå knyttet til flyktninger og asylsøkere. Innvandrerne har en helt annen aldersfordeling enn norske statsborgere. Det er en sterk konsentrasjon av unge voksne, særlig blant menn, og svært få gamle. Andelen barn (0-6 år) blant statsborgere fra den tredje verden er nesten 15 prosent, mot bare 9 prosent i befolkningen ellers.

Høy arbeidsledighet blant innvandrere fra den tredje verden Andelen arbeidstakere blant innvandrerne varierer sterkt med botiden i Norge. Jo lenger tid en har bodd i Norge, jo høyere andel. Denne sammenhengen er klarere jo fjernere land innvandrerne kommer fra.

Den registrerte arbeidsløsheten i 1991 var på vel 18 prosent blant innvandrere fra den tredje verden, en økning fra omkring 7 prosent i 1987.

....på tross av høyt utdanningsnivå

Nivået på innvandrernes utdanning er i gjennomsnitt høyt, også blant innvandrere fra den tredje verden. Sammenhengen mellom inntekt og utdanning er imidlertid mye sterkere for nordmenn og vestlige innvandrere enn den er for innvandrere fra den tredje verden.

Statsborgere fra land i den tredje verden har et høyt forbruk av økonomisk sosialhjelp. Hele 23 prosent fikk økonomisk sosialhjelp i 1991. Blant enslige menn fra disse landene var andelen om lag 45 prosent. Innvandrere som har bodd i Norge i minst tre år, får stemmerett ved lokalvalg. Valgdeltakelsen er klart lavere enn for norske statsborgere (39 mot 66 prosent i 1991), og den har sunket noe for begge grupper siden valget i 1983.

\section{Kapittel 1 Levekår i Norge. Er graset grønt for alle}

1.14 Noen sentrale fordelingsdimensjoner

1.14.1 Forskjeller i levekår mellom menn og kvinner

1.14.2 Generasjoneforskjeller i levekår 


\subsection{NOEN SENTRALE FORDELINGSDIMENSJONER}

Kjønn, generasjon, bosted og sosioøkonomiske gruppe beskriver sentrale fordelingsdimensjoner i det norske samfunn. Utvalget har derfor funnet det riktig å drøfte levekår og levekårsfordeling også ut fra slike inndelinger.

1.14.1. Forskjeller i levekår mellom menn og kvinner Økt likestilling på vesentlige områder....

På vesentlige områder er det utvilsomt blitt mindre forskjeller i levekår mellom menn og kvinner. Et sentralt trekk ved utviklingen på 1980-tallet var økningen i sysselsettingsandelen blant kvinner, spesielt kvinner $\mathrm{i}$ småbarnsfasen. Sysselsettingen blant menn gikk ned. Det er også mye som taler for at lønnsforskjellene mellom menn og kvinner ble mindre i løpet av tiåret. Kvinner inntok i høyere grad ledende posisjoner i samfunnslivet, og økte sin sosioøkonomiske status. Det skjedde en endring i retning av mer lik tidsbruk for menn og kvinner fra 1980 til 1990. Kvinnene økte sin tid i inntektsgivende arbeid, mens mennene økte sin tid i ulønnet husholdsarbeid. ....men også økte problemer for kvinner Nedgangen i andelen med lav materiell standard i løpet av 1980-tallet var mindre blant kvinner enn menn. Kvinners helse og fysiske miljø utviklet seg mindre positivt enn for menn. Andelen med muskel-/skjelettlidelser økte blant kvinner i yrkesaktiv alder i løpet av 1980-tallet, mens den var uendret for menn. Færre kvinner har nå et godt fysisk arbeidsmiljø. Fremdeles er det riktignok slik at menn har et dårligere fysisk arbeidsmiljø enn kvinner, men forskjellene er blitt mindre. Dels skyldes dette at flere kvinner er sysselsatte, men det skyldes også at en økende andel sysselsatte kvinner rapporterer om ulike fysiske belastninger i arbeidsmiljøet.

Det er også grunn til å påpeke at det fremdeles er betydelige forskjeller i menns og kvinners livssituasjon. Blant annet står vi fortsatt overfor et sterkt kjønnsdelt arbeidsmarked, hvor kvinneyrkene er dårligere lønnet. Selv om kvinneandelen blant ledere har økt, er fremdeles de langt fleste ledere menn.

\subsubsection{Generasjonsforskjeller i levekår}

Generasjonsforskjeller i etableringsmønstre

Dagens befolkning er sammensatt av aldersgrupper som befinner seg i ulike livsfaser og stadier av livsløpet. De som ble født tidlig i dette århundret hadde en langvarig etableringsfase. Fødselskullene ble tidlig selvforsørgende, men mange etablerte seg relativt sent i livsløpet med egen familie. Dette mønsteret endret seg for dem som ble født senere i dette århundret. Fødselskullene mellom 1920 og 1950 hadde en tidsmessig sammentrengt etableringsfase: Flere tok utdannelse utover folkeskolen, samtidig som familieetableringen ble flyttet betydelig nedover mot yngre alderstrinn.

Tidlig på 1970-tallet snudde imidlertid denne tendensen. De senere fødselskullene, dvs. de som ble født etter 1950, har i større grad utsatt både den økonomiske og den familiemessige etableringen til senere faser av livsløpet enn det som var det typiske mønster til fødselskullene fra 1940-tallet, tildels også fra 1930-tallet. Et viktig unntak her er for kjøp av egen bolig.

Levekårskonsekvenser av ulike etablerings- mønstre Disse ulikhetene har også preget levekårsutviklingen for de ulike fødselskullene senere i livsløpet: Etableringsfasen til de som var født på 1940-tallet var i betydelig grad preget av økonomisk sårbarhet pga. kort tidsavstand mellom avsluttet utdanning og familieetablering. 1950-tallskullene hadde en lengre 
ungdoms- og etableringsfase. De tok mer utdanning enn 1940tallskullene, men strakk også utdanningen lenger ut i tid.

Kombinasjon av inntektsgivende arbeid og utdanning var mye mer vanlig i disse fødselskullene. De etablerte seg like tidlig i samboerskap, men utsatte i større grad å få barn til seinere faser av livsløpet.

Disse endringene i familieetableringsmønsteret bidro trolig til at 1950-tallskullene i utgangspunktet kunne gå inn i småbarnsfasen bedre økonomisk rustet enn fødselskullene før dem. De hadde også flere valgmuligheter i etableringsfasen enn de eldre fødselskullene pga. dereguleringen av bolig- og kredittmarkedet. På noen områder møtte de også større vansker, først og fremst i større grad enn 1940-tallskullene. De ble utsatt for en økonomisk lavkonjunktur i etableringsfasen, og de har også i høyere grad slitt med høy gjeld i småbarnsfasen.

Større utdanningsmuligheter i yngre fødselskull

Ett karakteristisk trekk som skiller

etterkrigsgenerasjonene fra dem som ble født tidlig i dette århundret, er den sterke økningen i omfanget av utdanning utover den obligatoriske skolegangen. Det har også skjedd en betydelig utjevning mellom kjønnene i andelen som har fått utdanning. Andelen av årskullet som har tatt utdanning på gymnas/videregående skolenivå eller høyere økte fra 18,8 prosent for menn i 1911-kullet til 63,7 prosent for menn i 1961-kullet. For kvinner var veksten fra 6,7 prosent til 59,6 prosent for de samme fødselkullene. Blant de yngre fødselskullene har det også skjedd en betydelig regional utjevning i utdanningsmulighetene. Endringer i levekår for ulike generasjoner 1980-1991: Nedgang i sysselsettingen for de eldre....

Datamaterialet fra levekårsundersøkelsene 1980 og 1991 tyder ikke på dramatiske endringer i levekårene for de enkelte fødselskullene i denne perioden. Endringer og forskjeller for de enkelte fødselskull kan dels knyttes til ulikheter i livsfase og dels til ulikheter som er etablert tidligere i livsløpet. Noen endringer er også mer generelle endringer på 1980-tallet som i større eller mindre grad slår ut i samtlige fødselskull.

Det var betydelige endringer i sysselsettingsnivået fra 1980 til 1991 innen de enkelte fødselskullene. Blant menn var det bare de som var under 40 år i 1991 (dvs. født etter 1950) som hadde økning i sysselsettingsfrekvensene fra 1980 til 1991. For de eldre var det nedgang, sterkere jo eldre mennene var. Derimot hadde kvinner som var under 50 år i 1991 (dvs. født etter 1940), en økning i andelen som vanligvis var i lønnet arbeid fra 1980 til 1991. Nedgangen i sysselsettingsfrekvensene for de eldre kvinnekullene var også mindre sterk enn for mennenes vedkommende. Det har med andre ord skjedd en utjevning mellom sysselsettingsfrekvensene for menn og kvinner, ikke bare på totalnivå, men også innen de enkelte fødselskullene.

.... og økning i ledighet for de yngre

Økningen $\mathrm{i}$ andelen langtidsledige var sterkest i de yngste aldersgruppene, og var svakt høyere for kvinner enn for menn. Andelen langtidsledige økte ikke fra 1980 til 1991 i de eldste fødselskullene. Dette må sees i sammenheng med at disse aldersgrupper har hatt en sterkere permanent avgang fra arbeidsstyrken ved alderspensjonering og en betydelig økning $\mathrm{i}$ andelen uførepensjonerte.

Boligstandard og materielle goder: Bedring for alle alderskull Det var en klar forbedring av den generelle boligstandarden i løpet av 1980-tallet: For alle født etter 1920 var det færre som bodde trangt i 1991 sammenliknet med 1980. Andelen som fortsatt bodde trangt i 1991 var betydelig lavere på alle alderstrinn enn i de tilsvarende alderstrinn i 1980. De samme endringer skjedde for andelen som manglet bad og wc i boligen. 
Stadig flere eldre har egen bil

Blant årskullene som var i ferd med å bli pensjonister på

1980-tallet var det en mye høyere andel som hadde bil enn i de

eldre aldersgruppene. Det var også en klar tendens til økning i

andelen som bor i hushold som eier fritidshus. Det var først og

fremst for de mellom 35 og 55 år at andelen fritidshuseiere økte, $\mathrm{i}$ eldre fødselskull reduseres andelen som hadde fritidshus med

alder.

Sosiale kontakter: Økt andel aleneboende

Andelen som bor alene økte stort sett $\mathrm{i}$ alle fødselskull, unntatt for kvinner født mellom 1941 og 1960 og for menn født mellom 1941 og 1950. Det er en høy andel aleneboende blant de eldre kvinnene.

Kapittel 1 Levekår i Norge. Er graset grønt for alle

1.14 Forskjeller i levekår mellom sosioøkonomiske grupper

1.14.3 Regionale variasjoner i levekår

1.14.4 Bydelsforskjeller i levekår

\subsubsection{Forskjeller i levekår mellom sosioøkonomiske grupper}

Endringer i sosial og økonomisk struktur

Den sosiale og økonomiske strukturen i befolkningen

endret seg på 1980-tallet. Det ble færre ufaglærte arbeidere,

lavere funksjonærer, bønder, fiskere og andre selvstendige. Til

gjengjeld ble det flere funksjonærer på mellomnivå og høyere.

Den sysselsatte del av befolkningen fikk med andre ord en høyere

sosioøkonomisk status i løpet av tiåret. Kjønns- og

alderssammensetningen av de ulike gruppene varierer mye.

Arbeiderne, spesielt de faglærte, er menn, mens de lavere

funksjonærene for en stor del er kvinner. Ungdom er naturlig nok

overrepresentert i de underordnede posisjonene; blant lavere

funksjonærer og ufaglærte arbeidere.

Fremdeles store forskjeller i rekrutteringen til høyere utdanning

Den viktigste inngangsbilletten til de overordnede

posisjonene i arbeidslivet er høyere utdanning. Det er fremdeles

en sterk tendens til at de som kommer fra hjem med lav sosial og

økonomisk status i mindre grad tar høyere utdanning enn andre.

Det er også flere i laveste enn i høyeste sosialgruppe som ikke

har fullført noen utdanning utover grunnskolen.

Ledigheten rammer mest de med lav utdanning

Personer som arbeider $\mathrm{i}$ de underordnede posisjonene $\mathrm{i}$

arbeidslivet er mer utsatt for arbeidsledighet enn andre

sysselsatte. Det ser derimot ikke ut til å ha blitt større ulik- heter

i fordelingen av arbeidsledigheten de siste årene. Ledigheten fra

1983 til 1991 økte mest blant personer med høyere utdanning.

Ulikheten mellom sosioøkonomiske grupper kan imidlertid ha økt

på andre måter, for eksempel ved at flere ufaglærte arbeidere og

lavere funksjonærer har gått over på uførepensjon eller

førtidspensjon. En indikasjon på at dette kan ha skjedd, er at

nedgangen i yrkesaktiviteten blant eldre menn på 1980-tallet

særlig har rammet de med lav utdanning.

Vedvarende store forskjeller i fysisk arbeidsmiljø

Knapt noe skaper større forskjeller mellom yrker $\mathrm{i}$

arbeidslivet enn belastningene i arbeidsmiljøet. Arbeidere, bønder

og fiskere er langt mer utsatt for fysiske belastninger i

arbeidsmiljøet enn andre grupper. I 1991 var en av fem arbeidere

utsatt for minst ti fysiske arbeidsmiljøproblemer, mens andelen i 
funksjonærgruppen var forsvinnende liten. Disse ulikhetene har vært nokså stabile det siste tiåret. Det har vært en viss forverring av arbeidsmiljøet blant lavere funksjonærer.

Større forskjeller i arbeidstidordninger

Det er en tendens til økte forskjeller i

arbeidstidsordninger mellom de sosioøkonomiske gruppene. Det er blitt mindre vanlig med dagarbeid og mer vanlig med skift- og turnusarbeid blant arbeidere og lavere funksjonærer. Samtidig er det en tendens til mindre ulikheter i graden av selvbestemmelse og variasjon i arbeidet. Det er likevel fremdeles store sosiale forskjeller i oppfatningen av yrket. 31 prosent av ufaglærte arbeidere og bare 6 prosent av høyere funksjonærer synes arbeidet er lite variert.

På tross av disse forskjellene, er det noen flere høyere funksjonærer enn arbeidere som opplever arbeidet som en psykisk påkjenning.

Fortsatt betydelige forskjeller i dødelighet og sykelighet Det er fortsatt betydelige forskjeller i dødelighet og sykelighet mellom ulike yrkesgrupper. I perioden 1980-90 var dødeligheten i den mest utsatte yrkesgruppen blant menn (underordnede innen skipsfart) mer enn dobbelt så høy som i den minst utsatte gruppen (pedagoger). Generelt er dødeligheten høyest i yrkesgrupper med lav sosioøkonomisk status. Forskjellene er omtrent tilsvarende i fordelingen av sykelighet. Arbeidere har mellom to og tre ganger så høyt sykefravær som funksjonærer.

Høyest årslønn for private funksjonærer En arbeider i en NHO-bedrift tjente i gjennomsnitt i 1992 i overkant av 190000 kroner, det samme gjaldt for kommuneansatte. Funksjonærer i NHO-bedrifter tjente i gjennomsnitt nærmere 250000 kroner samme år, av disse tjente ledende funksjonærer 360000 kroner. Den gjennomsnittlige årslønnsveksten i perioden 1982-1992 var sterkest blant ansatte i forretningsmessig tjenesteyting, varehandel og blant funksjonærer i NHO-bedrifter. Stats- og kommuneansatte var blant de gruppene som hadde lavest lønnsvekst i perioden.

Stabil økonomisk fordeling

Analyser av fordelingen av inntekt mellom ulike sosioøkonomiske grupper tyder ikke på noen vesentlige endringer i inntektsulikheten på 1980-tallet. Forskjellene i andelen lavtlønte (under 85 prosent av gjennomsnittlig industriarbeiderlønn) mellom de sosioøkonomiske gruppene har endret seg lite på 1980-tallet. Andelen lavtlønte var gjennom hele 1980-tallet høyest blant lavere funksjonærer.

Fordelingen av frynsegoder i arbeidet forsterker forskjellene i materielle belønninger knyttet til ulike posisjoner i arbeidslivet. Høytlønnsgruppene har oftere konkrete frynsegoder i jobben enn lavlønnsgruppene. Også disse forskjellene endret seg lite på 1980-tallet.

På bakgrunn av forskjellene i lønn og andre materielle belønninger, er det ikke overraskende at lavere funksjonærer og ufaglærte arbeidere noe oftere tilhører husholdninger som har økonomiske problemer enn andre yrkesgrupper. Bønder og fiskere oppgir også forholdsvis sjelden at de har økonomiske problemer. Forskjellen mellom ulike grupper av ansatte i omfanget av økonomiske problemer økte ikke fra 1987 til 1991.

Utjevning i tilgang til telefon og bil...

Fordelingen av tilgangen til andre materielle goder er enten stabil eller har blitt mere lik. På 1980-tallet var det en utjevning mellom de sosioøkonomiske gruppene i tilgangen til bil og telefon, mens ulikhetene i tilgangen til fritidshus var stabile. 
Gjennom hele 1980-tallet var det minst vanlig å eie fritidshus blant ufaglærte arbeidere og lavere funksjonærer.

....og i bostandard

I løpet av 1980-tallet skjedde det også en klar utjevning av ulikhetene i bostandard og i trangboddhet. Boligstandarden bedret seg mest blant bønder og fiskere, og blant arbeidere.

\subsubsection{Regionale variasjoner i levekår}

De regionale variasjonene i levekår er fremdeles

betydelige på enkelte områder, men hovedtendensen er likevel en utjevning av levekårsforskjellene i løpet av det siste tiåret.

Fortsatt betydelige forskjeller i dødelighet mellom fylkene Både for menn og kvinner er dødeligheten høyest $\mathrm{i}$

Finnmark og lavest i Sogn og Fjordane. Når vi tar hensyn til alderssammensetningen er dødeligheten blant menn i Finmark 40 prosent høyere enn i Sogn og Fjordane. Hovedinntrykket er at de fylkesvise forskjellene i dødelighet har vært ganske stabile de to siste tiår. For menn tyder tallene på litt synkende dødelighet $\mathrm{i}$ Finnmark i forhold til landsgjennomsnittet, og slik sett minker den regionale ulikheten i dødelighet. Blant kvinner er ikke ulikhetene blitt mindre.

Mindre gunstig arbeidsmarkedsutvikling i Oslo og

Østlandsområdet

Arbeidsmarkedet utviklet seg forskjellig i ulike regioner i løpet av 1980-tallet. Utviklingen var minst gunstig i Oslo og Østlandsområdet. Nedgangen i tallet på arbeidstakere etter 1987 var sterkest i denne delen av landet. På slutten av 1980-tallet fikk Norge "storbyledighet". Oslo, som tradisjonelt har hatt lav ledighet, hadde høyere registrert ledighet i 1991 enn landsgjennomsnittet. I perioden 1984-91 sett under ett var ledigheten størst helt i nord og helt i sør, med Østfold, Telemark, Aust-Agder og de fire nordligste fylkene på ledighetstoppen.

Akershus og Sogn og Fjordane hadde lavest registrert arbeidsledighet i hele perioden.

Regional utjevning i ledighetsnivået

Ledigheten var skjevere fordelt under forrige lavkonjunktur (1983-84) enn i 1991. Utjevningen av ledighetsnivået på slutten av 1980-tallet har sammenheng med at fylker som tradisjonelt har hatt høy ledighet har fått en høyere andel av arbeidsmarkedstiltakene enn tidligere. De tre nordligste fylkene hadde en markert høyere brutto ledighet (registrert ledige pluss personer på tiltak) enn de andre fylkene i 1991.

Regional utjevning i inntektsnivå

Fra 1987 til 1991 hadde særlig Oslo, men også Akershus, langt svakere vekst i nettoinntekten pr. innbygger enn landet forøvrig. Fylkene fra Nord-Trøndelag og nordover hadde den sterkeste veksten. Dette innebar en regional utjevning i inntektsnivået, siden veksten i nettoinntekten var svakest i fylker med høy inntekt og størst i fylker med relativt lav inntekt. Regionale ulikheter i husholdningens disponible inntekt pr. forbruksenhet er mindre enn for nettoinntekt pr. innbygger. Disponibel innntekt pr. forbruksenhet var i 1990 høyest i Oslo og Akershus (112 prosent av landsgjennomsnittet) og lavest i NordNorge (94 prosent av landsgjennomsnittet).

Oslo: Høy inntekt, men mange har økonomiske problemer På tross av høy inntekt er likevel andelen som mottar økonomisk sosialhjelp mer enn 50 prosent over landsgjennomsnittet i Oslo. Også andelen som oppgir at de har økonomiske problemer er over landsgjennomsnittet i Oslo.

Andelen som opplevde ulike former for økonomiske problemer ble om lag fordoblet i Oslo fra 1987 til 1991.

Regional utjevning i boligstandard

Det har vært en bedring i boligstandarden i alle 
landsdeler, men bedringen har jevnt over vært noe større i landsdeler med dårligst standard, slik at de regionale forskjellene er blitt redusert. En tilsvarende utvikling kan en se i forholdet mellom boligstandard i spredtbygde strøk og de store byene. Det har også skjedd en klar utjevning i eierforhold mellom landsdeler, og mellom by og land.

Derimot tyder ikke opplysninger en har om omfanget av støy og forurensninger, på noen regional utjevning i slike belastninger.

\subsubsection{Bydelsforskjeller i levekår}

Høy andel med levekårsproblemer i Oslos østlige bydeler I storbyene er det en sterk tendens til opphopning av levekårsproblemer i noen bydeler. Andelen av den voksne befolkningen som opplever problemer i forhold til arbeidsmarked, økonomi og helse synes å være langt større i enkelte bydeler i Oslo enn det som er vanlig ellers i landet. Framfor alt gjelder dette de tre østlige sentrumsbydelene (Sagene/Torshov, Gr nerløkka/Sofienberg og Gamle Oslo) og drabantbyen Romsås lengst øst i Oslo. Antallet sosialhjelpstilfeller i disse bydelene er om lag tre ganger høyere enn ellers i landet, og arbeidsledigheten blant menn er uvanlig høy, i to av bydelene omtrent det dobbelte av landsgjennomsnittet. Dødeligheten i aldersgruppen 60-74 år i årene 1988-90 var i gjennomsnitt 82 prosent høyere i disse bydelene enn gjennomsnittet for alle norske kommuner, mens snittet for de tre bydelene med lavest dødelighet (Vindern, Ullern og Røa) var 24 prosent under landsgjennomsnittet.

Sentrumsbydeler i storby: Mye trafikk, lavere bostandard

Både de østlige og vestlige sentrumsbydelene i Oslo tilhører de mest trafikkutsatte områdene i landet. Mellom $30 \mathrm{og}$ 40 prosent av husholdningene i sentrumsbydelene opplevde trafikken på nærmeste vei som plagsom, mens andelen i hele landet var 15 prosent i 1988. Samtidig er boligmassen eldre og mindre moderne enn i andre deler av landet. Opplysningene om tilsvarende variasjoner i Bergen og Trondheim er mer begrensede, men indikatorer på boligstandard og inntekt tyder på tilsvarende variasjoner. Som i Oslo er bostandarden i Bergen dårligst i sentrumsbydelene.

Bakgrunnen for bydelsforskjellene er først og fremst den sterke graden av sosial, økonomisk og demografisk sortering av personer i storbyene. Bosatte i de østlige bydelene i Oslo har blant annet langt lavere utdannings- nivå og lavere inntekt enn bosatte i de vestlige bydelene. Sorteringen omfatter også statsborgerskap. Antallet personer med statsborgerskap fra den tredje verden er i langt høyere grad bosatt i de østlige bydelene i Oslo enn i Oslo og landet som helhet. Denne gruppen har blant annet større problemer i forhold til arbeidsmarkedet enn andre grupper.

Større levekårsproblemer i Oslo øst enn i mange andre kommuner

En enkel indeks, som sammenfatter informasjonen i fire mål på levekårsproblemer (sosialhjelp, dødelighet, arbeidsledighet og uførepensjon), tyder på at det bare var 16 kommuner i landet som hadde like hyppige levekårsproblemer som befolkningen i bydelene Sagene/Torshov, Gr nerløkka/Sofienberg, Gamle Oslo og Romsås ved inngangen til 1990-tallet. Omkring 75000 mennesker bor i disse delene av Oslo, like mange som i Finnmark fylke. På den andre siden var det knapt noen kommuner i landet som hadde færre levekårsproblemer enn enkelte av de vestlige bydelene, spesielt Vindern. 
NOU 1993:17

side 46 av 46 